\title{
5. Transnational Mapuche Advocacy
}

Mapuche representatives travelling abroad, the Mapuche diaspora in Europa, and multiple non-Mapuche supporters and organisations take part in transnational Mapuche advocacy (TMA). This chapter will present and critically discuss the political strategies and tactics that are involved in TMA and employed by these different actors. The first section argues that the main reason for making particular and structural injustices internationally visible is the domestic blockage of political articulation of Mapuche organisations and communities in Chile. I will hereby suggest a master frame and three injustice frames as the key reference points for TMA and critically discuss their colonial limitations. The subsequent sections will present the main strategies and particular tactics within TMA. These include the informational politics-particularly digital Mapuche media and activism; the creation of transnational pressure against powerful actors through symbolic, leverage, and accountability politics; and the fortifying of Wallmapu as a strategy that aims to support the Mapuche society directly. Finally, I will suggest how transnational advocacy of and with the Mapuche becomes 'Mapuchised' through a series of (trans)cultural techniques and dialogues.

Political strategies and tactics within TMA respond to "two extreme and contradictory temporalities" between urgency and civilisational change (Sousa Santos 2018, 49-53; my translation). Political strategies are efforts that are performed in the long run, over years or decades, and address mostly structural sociopolitical, legal, economic, and cultural issues. In contrast, political tactics are efforts or sets of action that aim to change a particularly urgent issue or case of injustice. Hence, they are employed for a certain amount of time until the hazard or injustice is no longer a threat. In the case of the Mapuche, political strategies are directed at their sociopolitical, economic, and cultural marginalisation in Chile, their struggle for decolonising their territory, and the racialised criminalisation and persecution by 
the Chilean executive and judicial branches. Political tactics are activated contingently when these structural issues express themselves in a particular moment, for example the unjustified incarceration of a Mapuche leader. The present chapter focuses on those political strategies and tactics that are at work on an international level, transnationalising the struggle of the Mapuche and their advocacy.

\section{The Domestic Blockage and Transnational Framing of Mapuche Advocacy}

The main reason for the need for transnational advocacy is the domestic blockage of contemporary Mapuche mobilisation in Chile. ${ }^{1}$ This domestic blockage channels particular and structural issues to the international sphere and articulates them within wider master or injustice frames. The relationship between the contemporary Mapuche movement and the Chilean government is highly conflictive. The Mapuche movement responds with acts of nonviolent resistance against the militarisation of Wallmapu and their persecution and criminalisation. In that situation, the Chilean state lacks the will for a political dialogue and creates a domestic blockage for Mapuche organisations and communities who are not able to influence policy changes within the constraints of the political institutions of Chile. In order to bypass this domestic blockage, contemporary Mapuche mobilisations have been seeking the support of international allies. In theory, the political claims and information of a domestic movement are passed on to these international actors, who then advocate for the domestic movement in the transnational sphere or put pressure on the particular state that is responsible for the blockage. In that way, transnational advocacy works like a boomerang (Keck and Sikkink 1998, 12-14).

In the case of Chile, various elements contribute to the particular colonial dynamic where the demands of the Mapuche are being structurally blocked from articulating and materialising their claims within the domestic political system. To begin with, in its constitution the Chilean state is defined as "unitary" and sovereignty lies essentially within "the Nation" (Ministerio del

1 By contemporary Mapuche mobilisation in Chile, I mostly refer to the actors, organisations, and communities of the autonomist Mapuche movement identified in the previous chapter. 
Interior 1980, 5; my translation). No other individual or group can claim that right. The claim of autonomy and self-determination by the Mapuche is thus structurally limited by the constitution, because it counters the unitary and mononational self-understanding of the Chilean nation-state. For example, although ILO Convention 169, as one of the most advanced legal frameworks to secure Indigenous rights, has been ratified by the Chilean state in 2008 , none of its most central aspects, amongst them constitutional recognition, has been put into practice by the Chilean government (Habersang and Ydígoras 2015, 261-73). The current conflict dynamic in Wallmapu needs to be understood as a consequence of the historical negation of the Mapuche as a distinct nationality. This situation demands a political answer on the basis of accepting Chile's plurinationality, as Federico Aguirre (interview with the author, March 2, 2016) from the INDH claims. Plurinationality and interculturality are thus the core demands of Mapuche mobilization within the current context of the elaboration of a new constitution (Pairican 2021).

A particular Chilean phenomenon of the blockage or-more accurately-repression of the Mapuche movement is that political expressions of the Mapuche have been constantly criminalised by the Anti-Terrorist Law 18.314 since the late 1990s until the present day (Emmerson 2014). By 2010, more than 50 Mapuche were arrested under the Anti-Terrorist Law (Human Rights Watch 2011). Also, the National Security Law legitimises the incarceration of a large number of Mapuche community members. In that context, police operations lead to the torture and abuse of the Mapuche population, amongst the women and children (Millaleo Hernández 2011). At the same time, the Mapuche population has been increasingly framed as terrorists by biased media campaigns (Kaufmann 2010). Also, the rights to freedom of peaceful assembly and of association are severely limited in Chile (Kiai 2016, 19). ${ }^{2}$

Within the Chilean legal system, the high costs of legal services, language barriers, and "fear and distrust towards, and their past experience with the Chilean judicial apparatus" (Skjævestad 2008, 8) are all obstacles for the Mapuche population. During my activist ethnography in 2016, I was able to compare two particular court cases where sentencing was radically different: in one case, a Mapuche was declared guilty of an arson attack; in the other, a Chilean individual was declared guilty of having murdered a Mapuche protester. In the former case, Guido Carihuentru was sentenced to eight 
years in prison and the compensation payment of 1,000 USD that he offered was denied; in the latter, José Cañete was sentenced to five years in prison and his compensation payment of 870 USD to the family of the victim, José Quintriqueo Huaiquimil, was accepted by the court. This case shows that there exists a racial bias within the Chilean legal system that disproportionally disadvantages the Mapuche population. Guido Carihuentru's lawyer, Sebastián Saavedra, put it in more drastic words by claiming that apparently in the Araucanía region it is cheaper to kill a Mapuche than to burn down a truck (Garbe 2016a).

As a consequence of the colonisation of Wallmapu from the end of the nineteenth century, the Mapuche society has been spatially marginalised and segregated into small lots of land across the Araucanía region and within impoverished urban neighbourhoods. The spatial marginalisation and segregation further accentuate the lack of access to the labour market, housing, social services, health, or education and jeopardises their equal participation as political citizens. At the beginning of the century, 35.6 percent of the Indigenous population in Chile lived under the poverty line, compared with 22.7 percent of the non-Indigenous population. Furthermore, the absolute and relative poverty rates of the Mapuche population are considerably higher than those of other Indigenous populations in Chile. These factors are expressions of the structural discrimination against the Mapuche population regarding access to education and health infrastructure (Kaltmeier 2004, 211-16).

Despite the return to democracy in Chile, the Mapuche society lacks proper representation within the Chilean political system. Whilst the overall Indigenous population in Chile has been successful in their struggle to achieve some degree of political representation, foremost through the $\mathrm{CONADI}^{3}$ or seats in the two legislative chambers, there is a lack of Mapuche organisation and representation on the level of civil society, which would articulate demands by the Mapuche on a national scale or pressure institutions and officials to act in their favour. Here, especially the biased and racially loaded stereotypes of the Mapuche as terrorists, criminals, and lazy people in the national media contribute to the systematic exclusion of the Mapuche from public debates and discussions.

As a consequence, the Chilean state has failed to adequately respond to demands of the Mapuche society for intercultural education. Rather than decolonising the national educational system and incorporating Mapuche 
knowledge, language, and cosmology into the educational canon on equal terms, racist and colonial imaginaries towards Indigenous people in Chile are reproduced, mobilised for a neoliberal agenda, and efficiently used to control "the complex panorama of ethnic conflict in southern Chile" (Lepe-Carrion 2016, 62).

These structural limitations and impediments to participate equally in the political arena have led to a frustration and distrust amongst the Mapuche society of representatives and institutions of the (white) Chilean state. These exclusions create the need to look for political answers within the Mapuche society itself by referring to its cultural politics of autonomy. The national belonging of the Mapuche is thus a consequence of their structural limitation and discrimination within Chilean society, as well as their own self-understanding as an autonomous but colonised nation. This leads to a situation of general suspicion towards or even incompatibility with engagement and participation within and with the Chilean political institutions, parties, or ideologies. In that way, the Chilean political system becomes further blocked off to the Mapuche.

Consequently, the central actors of the Mapuche society who are blocked from participating in Chilean political institutions are its more autonomist sectors. These communities and organisations reach out internationally to the Mapuche diaspora and non-Mapuche organisations and actors to bypass that blockage, hereby weaving the solidarity networks. However, instead of targeting particular nation-states, the main addressees of their advocacy are a transnational civil society within mostly Western European countries and supranational organisations. But the advocacy is not delegated completely to the diaspora or non-Mapuche actors. Instead, Mapuche organisations and communities from Wallmapu weave their own web of alliances in which advocacy work takes place. Therefore, instead of delegating tasks to a non-Mapuche advocacy network, they maintain their autonomy in advocacy.

In theory, a transnational advocacy network foremost seeks to pressure a particular nation-state to change its policy, laws, constitution, etc. (Keck and Sikkink 1998). The final success of such advocacies would lie in the legal recognition of a (particular or structural) injustice or constitutional recognition as a distinct nationality, as many Mapuche organisations and communities claim. However, Coulthard's (2014) decolonial analysis of the Canadian context warns that legal or political recognition within the nation-state (and, I would add, within transnational organisations) can reproduce or even reinforce colonial 
relationships that continue to marginalise Indigenous people and their political articulations.

This argument helps to see why, in the present case, advocacy strategies go beyond the struggle for recognition within (inter)national political and legal structures. Instead, they are more diverse and include efforts to strengthen Mapuche communities and organisations directly or to establish a dialogue with them. This means that not only the blockage of the Chilean state but also its institutions, as a limited motor for change, are bypassed by the transnationalisation efforts. The reason is that the contemporary Mapuche mobilisation does not necessarily seek change within the Chilean nationstate, but aims instead at its transformation and decolonisation. The most central claims of the autonomist Mapuche movement, like autonomy, self-determination, and territory, are hardly possible under the current sociopolitical and legal structure of the state. These demands would transform and challenge its constitutionally inscribed mononationality and neoliberal, capitalist order. Thus, the transnational advocacy of the Mapuche movement and its international allies is a decolonial boomerang, which does not only aim at dissolving the blockage within the Chilean state, but rather points towards a radical reorganisation and transformation of the sociopolitical, economic, territorial, and constitutional order itself-that is, its decolonisation. What is more, these transnationalisation efforts contribute to rebuilding the sociocultural fabric and political institutions of the Mapuche society as an autonomous nation. In other words, the aim of political solidarity with Wallmapu is to reconstruct and decolonise social solidarity in Wallmapu.

Transnational advocacy networks usually address particular, as well as structural, issues. Particular issues mostly refer to "problems whose causes can be assigned to the deliberate (intentional) actions of identifiable individuals," whilst structural problems address "issues involving legal equality of opportunity" (Keck and Sikkink 1998, 27). In transnational advocacy with the Mapuche, both particular and structural issues are addressed.

During my ethnography from 2014 to 2017, several cases of human rights violations against the Mapuche were brought to international attention as particular cases. For example, from April 2016 to 2018, machi Francisca Linconao was accused under the Anti-Terrorist Law and held responsible for the murder of two Chilean landowners, who died as a consequence of an arson attack on their home. The court ultimately ruled that she was not responsible, but she was held in pretrial custody for one and a half years, suffering 
psychological and physical abuse. Another internationally known case is the murder of Macarena Valdés. On August 22, 2016, the Mapuche woman and mother of four was found dead, hanging from a tree in front of her home. Macarena Valdés and her husband Rubén Collío have been organising the resistance against a hydroelectric powerplant in their community and received several death threats prior to the incident. Whilst the official forensic examination declared her death a suicide, in 2018 an independent forensic doctor, financed through solidarity campaigns, ruled her death a homicide. The following chart sums up other high-profile individual cases between 2014 and 2017 that have been made prominent internationally, consistent with the definition of a "serious violation of international human rights law" by the Geneva Academy of International Humanitarian Law and Human Rights' $(2014,5){ }^{4}$

4 I would like to thank Sebastian Kratzer from the Centre for Humanitarian Dialogue in Geneva for suggesting a thorough and consistent terminology. 
Table 1. High-profile (individual) cases involving serious violations of international human rights against the Mapuche, 2014-2017

\begin{tabular}{|c|c|}
\hline Individual Case & Violations \\
\hline Guido Carihuentru & $\begin{array}{l}\text { Arbitrary or prolonged detention } \\
\text { Denial of the right to freedom of conscience/persecu- } \\
\text { tion of a religious group } \\
\text { Excessive use of force by security forces/dispropor- } \\
\text { tionate violence } \\
\text { Failure to fulfil procedural obligations (failure to in- } \\
\text { vestigate) } \\
\text { Obstruction of humanitarian and medical aid } \\
\text { Violation of right to a fair trial } \\
\text { Violation of the right to humane treatment in custody, } \\
\text { detention in degrading conditions }\end{array}$ \\
\hline Lorenza Cayuhán & $\begin{array}{l}\text { Arbitrary or prolonged detention } \\
\text { Excessive use of force by police forces } \\
\text { Cender-based violence } \\
\text { Negligence leading to serious risk to life or health } \\
\text { Torture or inhuman or degrading treatment by secu- } \\
\text { rity forces, prison officers or other public officials } \\
\text { Violation of the right to humane treatment in custody, } \\
\text { detention in degrading conditions }\end{array}$ \\
\hline Machi Celestino Cordóva & $\begin{array}{l}\text { Arbitrary or prolonged detention } \\
\text { Denial of the right to freedom of conscience/persecu- } \\
\text { tion of a religious group } \\
\text { Excessive use of force by security forces/dispropor- } \\
\text { tionate violence } \\
\text { Failure to fulfil procedural obligations (failure to in- } \\
\text { vestigate) } \\
\text { Violation of right to a fair trial } \\
\text { Violation of the right to humane treatment in custody, } \\
\text { detention in degrading conditions }\end{array}$ \\
\hline Felipe Durán & $\begin{array}{l}\text { Arbitrary or prolonged detention } \\
\text { Attack on human rights defenders and journalists } \\
\text { Failure to fulfil procedural obligations (failure to in- } \\
\text { vestigate) } \\
\text { Violation of right to a fair trial } \\
\text { Violation of the right to humane treatment in custody, } \\
\text { detention in degrading conditions }\end{array}$ \\
\hline
\end{tabular}




\begin{tabular}{|c|c|}
\hline Brandon Hernández Huentecol & $\begin{array}{l}\text { Excessive use of force by security forces/dispropor- } \\
\text { tionate violence } \\
\text { Violation of children's rights/violence against chil- } \\
\text { dren }\end{array}$ \\
\hline Machi Francisca Linconao & $\begin{array}{l}\text { Arbitrary or prolonged detention } \\
\text { Excessive use of force by security forces/dispropor- } \\
\text { tionate violence } \\
\text { Violation of right to a fair trial } \\
\text { Cender-based violence } \\
\text { Denial of the right to freedom of conscience/persecu- } \\
\text { tion of a religious group } \\
\text { Failure to fulfil procedural obligations (failure to in- } \\
\text { vestigate) }\end{array}$ \\
\hline Victor Queipul & $\begin{array}{l}\text { Abduction/kidnapping } \\
\text { Acts of intimidation, harassment and extortion } \\
\text { Detention in undisclosed locations } \\
\text { Excessive use of force by security forces/dispropor- } \\
\text { tionate violence } \\
\text { Failure to fulfil procedural obligations (failure to in- } \\
\text { vestigate) }\end{array}$ \\
\hline Macarena Valdés & $\begin{array}{l}\text { Extrajudicial killing or execution } \\
\text { Failure to fulfil procedural obligations (failure to in- } \\
\text { vestigate) } \\
\text { Violation of right to a fair trial }\end{array}$ \\
\hline $\begin{array}{l}\text { Children from a primary school } \\
\text { in Temucuicui }\end{array}$ & $\begin{array}{l}\text { Attacks on schools and education facilities } \\
\text { Deliberate/direct targeting of and indiscriminate at- } \\
\text { tacks on civilians/civilian objects and infrastructure } \\
\text { Excessive use of force by security forces/dispropor- } \\
\text { tionate violence } \\
\text { Violation of children's rights }\end{array}$ \\
\hline Pilmaiquen river & $\begin{array}{l}\text { Discrimination on racial, national, ethnic, linguistic, or } \\
\text { religious grounds } \\
\text { Denial of the right to freedom of conscience/persecu- } \\
\text { tion of a religious group }\end{array}$ \\
\hline
\end{tabular}


Structural issues that are being addressed within transnational advocacy usually relate to paradigmatic court cases $^{5}$ against Mapuche individuals-mostly spiritual and political leaders. Other structural issues include the demand for autonomy and self-determination, most prominently put forward in the "International Conference on the Mapuche Treaties or Parliaments" in The Hague in May 2015. Another example is August 2017, when several Mapuche leaders from various communities and organisations were arrested during the so-called 'Operation Hurricane,' which was knowingly based on false evidence produced by the Chilean secret police. Some of the internationally addressed structural issues between 2014 and 2017 as well as the condemnations are presented below.

5 For example, the so-called Luchsinger-Mackay case or the Church case, in which Mapuche community members remained in preventive detention based on dubious evidence and were denied their rights as Indigenous people guaranteed by ILO Convention 169. 
Table 2. High-profile (structural) cases involving serious violations of international human rights against the Mapuche, 2014-2017

\begin{tabular}{|l|l|}
\hline Structural Issues & Violations \\
\hline Luchsinger-Mackay Case & $\begin{array}{l}\text { Arbitrary or prolonged detention } \\
\text { Denial of the right to freedom of conscience/persecu- } \\
\text { tion of a religious group } \\
\text { Excessive use of force by security forces/dispropor- } \\
\text { tionate violence } \\
\text { Failure to fulfil procedural obligations (failure to in- } \\
\text { vestigate) } \\
\text { Violation of right to a fair trial }\end{array}$ \\
\hline Church case & $\begin{array}{l}\text { Arbitrary or prolonged detention } \\
\text { Denial of the right to freedom of conscience/persecu- } \\
\text { tion of a religious group } \\
\text { Excessive use of force by security forces/dispropor- } \\
\text { tionate violence } \\
\text { Failure to fulfil procedural obligations (failure to in- } \\
\text { vestigate) } \\
\text { Violation of right to a fair trial }\end{array}$ \\
\hline International Conference on the \\
Mapuche Treaties or Parliaments \\
$\begin{array}{ll}\text { Denial of the right to freedom of conscience/persecu- } \\
\text { tion of a religious group } \\
\text { Discrimination/segregation } \\
\text { Forced displacement/massive population displace- } \\
\text { ment/internal displacement } \\
\text { Violation of right to a fair trial }\end{array}$ \\
$\begin{array}{ll}\text { Denial of access to any legal process/violation of right } \\
\text { to a fair trial } \\
\text { Excessive use of force by security forces/dispropor- } \\
\text { tionate violence } \\
\text { Failure to fulfil procedural obligations (failure to in- } \\
\text { vestigate) } \\
\text { Violation of the right to property/destruction of prop- } \\
\text { erty and houses/large scale demolition of houses and } \\
\text { infrastructure }\end{array}$ \\
\hline
\end{tabular}




\begin{tabular}{|l|l|}
\hline March and April 2016 in Tirúa & $\begin{array}{l}\text { Acts of intimidation, harassment and extortion } \\
\text { Excessive use of force by security forces/dispropor- } \\
\text { tionate violence } \\
\text { Failure to fulfil procedural obligations (failure to in- } \\
\text { vestigate) }\end{array}$ \\
\hline $\begin{array}{l}\text { Most recurrent serious violations } \\
\text { of human rights against the Ma- } \\
\text { puche }\end{array}$ & $\begin{array}{l}\text { Arbitrary or prolonged detention } \\
\text { Denial of the right to freedom of conscience/persecu- } \\
\text { tion of a religious group } \\
\text { Discrimination on racial, national, ethnic, linguistic, or } \\
\text { religious grounds } \\
\text { Excessive use of force by security forces/dispropor- } \\
\text { tionate violence } \\
\text { Failure to fulfil procedural obligations (failure to in- } \\
\text { vestigate) } \\
\text { Cender-based violence } \\
\text { Violation of right to a fair trial } \\
\text { Violation of the right to humane treatment in custody, } \\
\text { detention in degrading conditions }\end{array}$ \\
\hline
\end{tabular}

Condemnations of individual human and Indigenous rights violations also point to structural issues that are being raised within transnational advocacy. This is because it might seem easier to raise awareness about structural issues by relating to a particular case of injustice. At the same time, there is a cyclical dynamic within the mobilisation for a particular case: if, for example, one political prisoner is discharged, the energies of that support are immediately mobilised for a different case.

Scholars of (new) social movements have proposed the conceptual tool of "frame alignment" through which movements establish connections with possible international supporters by rendering their motivations and claims meaningful. In that context, frames are "schemata of interpretation' that enable individuals 'to locate, perceive, identify, and label' occurrences within their life space and the world at large" (Snow et al. 2008, 255). Processes of frame alignment are considered crucial for a movement to attract international supporters and solidarity by contributing to "the construction of an interpretive scheme that simplifies and condenses the "world out there" (Tarrow 2011, 142). One particular approach is to develop an "injustice frame" by "inscribing grievances in frames that identify an injustice, attribute the re- 
sponsibility for it to others, and proposing solutions" (Ibid., 145). In this case, it is possible to identify one master frame and three overlapping injustice frames within transnational solidarity and advocacy with the Mapuche.

First, transnational solidarity and advocacy with the Mapuche is situated within "the complex of democratic and human rights ideas that have taken hold since the 1980 s on a more or less global scale provid[ing] a master frame in international framing processes" (Olesen 2005,44$)$. This process is also described as global framing, that is "the framing of domestic issues in broader terms than their original claims would seem to dictate" (Tarrow 2011, 235). Regarding the rights of Indigenous people, since the 1980 s there have been significant advances within the international legal architecture (Habersang and Ydígoras 2015, 11-14). The most important elements of this Indigenous and human rights frame are ILO Convention 169 in 1989, the UN Declaration of the Rights of Indigenous Peoples in 2007, and the Organisation of American States, especially its negotiation of the American Declaration on the Rights of Indigenous Peoples in 2016. Although ILO Convention 169 was ratified by Chile in 2008, a thorough analysis of its application shows that none of its articles have been respected in Chile ever since (Habersang and Ydígoras 2015, 266-73). What is more, the tables from above indicate a systematic violation not only of human rights, but particularly Indigenous people's rights. This master frame is continuously activated by defending (Indigenous) human rights and denouncing their violations. There have also been some positive results from bringing cases to institutions of the international legal structure in reference to this framework. ${ }^{6}$

Nevertheless, the present research seeks to recognise the limitations of such a political approach based on the Eurocentrism and underlying racism within the idea of human rights. This is because, as postcolonial and decolonial scholars like Nelson Maldonado-Torres, Gayatri Spivak, and Sylvia Winter have shown, the Western and Eurocentric notions of human rights are organised along a "modern/colonial-line," which imposes "a radical separation

For example, in July 2014 the Inter-American Court of Human Rights condemned the Chilean state for the application of the anti-terrorist jurisdiction in eight cases since 2002 (the longko Pichún case, International Federation for Human Rights 2014).Another successful and prominent example was a complaint sent to the Committee on the Elimination of Racial Discrimination (CERD) accusing the Chilean state of environmental racism. The complaint was taken up in 2007 by the CERD, who demanded a report from Chile, which was finally submitted two years later (Pantel 2015; Richards 2013, 222-23). 
between some humans and others" (Maldonado-Torres 2017, 123-24). Historically, this separation has legitimised the contradiction of denying rights for all humanity within colonisation or transatlantic enslavement, whilst affirming and theorising a universal claim of human rights. Against this contradiction, in critical decolonial interventions, human rights and 'humanity' are analysed as expressions of colonial, racialised, and gendered power structures, which results in the "performative contradiction of denying humanity in the very process of seeking to affirm human rights" (Maldonado-Torres 2017, 132). This refers particularly to transnational human rights advocacy, in which Western actors advocate for the human rights of marginalised and subalternised groups and silence them at the same time (Mahrouse 2014; Spivak 2004). In that sense, a critical perspective on TMA needs to recognise this colonial limitation of the human rights approach.

Regarding the injustice frames, the criminalisation, persecution, and violence against the Mapuche in Wallmapu is framed within more general and broader critiques of the military dictatorship in Chile from 1973 to 1990. The structural violation of human rights during the dictatorship has been widely acknowledged domestically and internationally-as well as historically revised by the Chilean state, for example through the national commission for truth and reconciliation (Federico Aguirre, interview with the author, March 2, 2016).

Nevertheless, from the point of view of the Mapuche and their solidarity actors, this "dictatorship never ended" (Alex Mora, interview with the author, November 28, 2015). Alex Mora has been engaging in solidarity action with the Mapuche in the last decade as a diasporic Mapuche. For him, a major motivation to join in solidarity efforts with the Mapuche was what happened to his brother, who was tortured during the dictatorship, resulting in his death. He also personally experienced the violence of police raids on his home, as the police searched for his brother and then beat him before his eyes. The story of Alex Mora exemplifies how an already acknowledged injustice frame regarding the dictatorship serves as a motivation to engage in solidarity action with the Mapuche. He experienced "in his own flesh" what is happening on an everyday basis in Mapuche communities like Temucuicui (Ibid.)

This particular injustice frame serves as a powerful tool for transnational advocacy, holding today's Chilean state accountable in light of the past human rights violations during the dictatorship. This strategy aims to counter the self-representation of Chile as a defender and guarantor of human rights, who has processed its dark past. Jaime Huenchullán explains that international 
solidarity has a subversive potential because "they [the Chilean political elite] do not want their external image getting stained" (interview with the author, March 20, 2016). This particular framing strategy can be interpreted as "frame amplification" (Snow et al. 2008, 257-58), wherein an interpretative frame regarding a particular situation (e.g., the dictatorship and its crimes) and its storytelling is updated (e.g., that the dictatorship never ended) and its memory invigorated (e.g., that similar crimes are still happening). This allows, on the one hand, to reach out to a possibly larger demographic within the Chilean or international civil society. On the other hand, it challenges the positive postdictatorial image of the Chilean state and demands compliance with human and Indigenous rights.

Transnational solidarity with the Mapuche has also been challenging the racialised stereotype of the Mapuche as terrorists. Since the late 1990s, biased right-wing media, like the national newspaper El Mercurio, have associated activities of Mapuche communities and organisations openly and directly with criminal, terrorist, violent, and aggressive actions. These discourses have developed a now widely accepted wording in Chilean society, in which the causes of the conflict are attributed solely to the Mapuche. They introduced the term 'Mapuche conflict' and successfully framed the conflictive situation in Wallmapu from a colonising perspective.

One expression of this negative frame is to associate and equate Mapuche mobilisation with armed insurgent organisations like the FARC in Colombia, ETA in Spain, or even Al Qaeda (Cayuqueo 2012, 74-76; 110-12; Kizugünewtun Independencia 2017). Moreover, the Catholic Church has also been responsible for spreading the image of the Mapuche as violent perpetrators through several media reports in Catholic online newspapers internationally. ${ }^{7}$ This negative frame is so powerful that, in its country-specific safety information, the German Federal Foreign Office warns about attacks on vehicles and roadblocks on highways in the eighth and ninth region, the surroundings of Temuco, and encourages tourists not to use highways in those regions (Auswärtiges Amt 2018). These examples not only discursively criminalise the political expressions of the Mapuche society, but also contribute to the legitimisation of factual repression and persecution.

For example, the conservative Bishop of Villarica, Javier Stegmeier, was interviewed in a German-speaking online newspaper and presented his partial and biased view on the conflict, claiming that Mapuche organisations are "part of the problem" (Kirche in Not 2016; my translation). 
One central aim of the Mapuche is to challenge this negative framing domestically and internationally. One task for the solidarity efforts by nonMapuche organisations and actors would be "that our [of the Mapuche] German friends over there [in Europe] say that it is not like that." In opposition to the violent stereotype, international solidarity should portray "the social proposal [of the Mapuche] as generally peaceful" (Vicente Painel, interview with the author, February 20, 2016). Countering the negative frame can be described as oppositional framing or "frame transformation," wherein "new values may have to be planted and nurtured, old meanings or understandings jettisoned, and erroneous beliefs or 'misframings' reframed" (Snow et al. 2008, 259).

Increasingly in recent years, domestic and international Mapuche mobilisation has framed their struggle in ecological terms. Examples include their opposition to land-grabbing by the monocultural agroindustry since the 1970 s (Miranda et al. 2017) or to the construction of hydroelectric power dams and wind farms (Cárdenas 2017; Martínez 2016) as forms of "green colonialism" (Heuwieser 2015; my translation). The ecological depravation of the Araucanía region $^{8}$ since the 1970s is one of the key topics within Mapuche media that has been taken up by a larger audience domestically and internationally. Thus, the sympathy for the protection of the environment and the critique of its capitalist exploitation can create solidarity amongst domestic and international non-Mapuche actors. ${ }^{9}$

In that way, they "extend the boundaries of its [the Mapuche movement's] primary framework so as to encompass interests or points of view that are incidental to its primary objectives but of considerable salience to potential adherents" (Snow et al. 2008, 258). Mapuche communities, organisations, and media have successfully extended the frame of their ecological struggle by articulating it within Western, and hence more hegemonic, concepts for envi-

The neoliberal land reform under the dictatorship made a dense concentration of landownership in Southern Chile through the privatisation of extensive territories possible, which heavily disadvantaged Mapuche communities and organisations and deprived them of their territory. Their struggle for an autonomous territory today is the consequence of this historical development and challenges the neoliberal order of private landownership in the Araucanía region. A struggle against the capitalist usage of natural resources in the form of plantations or power dams is thus a struggle for the right to land and territory.

9 See chapter six. 
ronmental justice ${ }^{10}$ but without renouncing their cosmological understanding of nature.

The rest of the chapter will outline four basic strategies of TMA that bypass the domestic blockage in Chile and support the decolonial struggle of the Mapuche in Wallmapu. A central aspect of TMA is to create and pluralise information in order to raise awareness about the situation of the Mapuche in Wallmapu. Amongst these informational politics, I will foremost highlight contemporary digital Mapuche media and activism. The informational politics are fundamental to creating and setting an agenda internationally by creating awareness about the situation and the demands of the Mapuche as an Indigenous society in Latin America. One aim of these politics is to create an influence and change discursive positions by non-Mapuche institutions, organisations, and actors (Keck and Sikkink 1998, 25).

TMA takes place within the decentral and rhizomatic solidarity network in Europe and is part of the struggle of Mapuche communities and organisations from Chile. One central characteristic of TMA is that, following the cultural politics of autonomy, primarily it is the Mapuche advocating for themselves, instead of non-Mapuche advocating for them. Advocacy is hereby just one expression of the international solidarity with the Mapuche, in which Mapuche from Wallmapu, the diaspora, and non-Mapuche organisations and actors take part.

The central actors of TMA weave the decentral solidarity network described in chapter four. Those are the Mapuche diaspora and its local groups and translocal connections across Europe, particularly the two more consolidated translocal networks IDNMP and the CME. They are supported by a series of non-Mapuche local groups and activists, as well as national and international NGOs, who also have direct ties to communities and organisations in Wallmapu. All these actors are engaged in transnational advocacy by linking the domestic with the transnational sphere, creating connections between civil societies, governments, and international organisations, and providing material and logistic support (Keck and Sikkink 1998, 1-2).

TMA defends or advocates for Indigenous rights by addressing a mostly non-Indigenous demographic and a series of "target actors" (Ibid., 3-4). The former includes NGOs, social and traditional media, different kinds of political actors, and the political public sphere. The latter includes national and 
international governmental bodies and representatives, international organisations, and private corporations, who are specifically addressed by the network's strategies and who might assume responsibility for a particular situation of injustice (Keck and Sikkink 1998; Tarrow 2011).

TMA uses different tactics to exert pressure on target actors in order to make them accountable and create leverage. The advocacy's influence and pressure hereby seek to challenge and transform institutional procedures whilst aiming for concrete changes in policies. They therefore target actors on an international level, as well as governmental behaviour on a national, regional, or local level (Ibid., 26). Especially because aiming at policy and institutional change domestically since the 1990s has been rather unsuccessful, Mapuche mobilisation has increasingly transnationalised itself. Through "transnational diffusion," Mapuche communities and organisations have "spread [...] similar forms of action and similar claims across borders" (Tarrow 2011, 235).

The strategies of informational politics and pressure can both be described as processes of "externalisation," where "domestic actors, frustrated by their inability to gain redress from their governments, mobilize against foreign or international targets" (Tarrow 2011, 254). Externalisation or internationalisation describe all those efforts by Mapuche organisations and communities in Wallmapu aimed at bypassing the blockage imposed by the Chilean state mentioned above.

A third strategy of TMA or international solidarity is not necessarily aimed at changing legal procedures or influencing the political decisions of the Chilean state, but at fortifying and strengthening Mapuche communities and organisations through concrete and material supportive acts. In that context, non-Mapuche actors and organisations contribute to the decolonising boomerang effect described above. Ultimately, TMA creates spaces of transcultural dialogue between Mapuche and non-Mapuche actors within the international solidarity network. These two strategies are rarely theorised in transnational social movement research, but are nevertheless part of the "transnational coalition formation" because they support "the creation of transnational networks to support cooperation across borders" (Tarrow 2011, 235).

In the present case, this transnational coalition formation is characterised by its decentral and rhizomatic network structure. Whilst this research differentiates between Mapuche and non-Mapuche, it is worth asking who forms a coalition with whom? Put differently, who is in solidarity with whom? For ex- 
ample, diasporic Mapuche are both outsiders and insiders to the dynamics in Wallmapu. To the Mapuche in Wallmapu, they might be outsiders since they live in Europe; for non-Mapuche actors, they might be considered insiders because of their ethnic identity. And doesn't the relationship between nonMapuche and diasporic Mapuche also produce solidarity? Consequently, it is necessary to focus on the heterogenous, contingent, and multiple coalitions that are formed in the context of TMA. These are the coalitions between Mapuche organisations and communities with international non-Mapuche organisations and actors, as well as with the Mapuche diaspora. Furthermore, the Mapuche diaspora and non-Mapuche activists and organisations form coalitions transnationally and translocally. All these coalitions contribute to the following advocacy strategies.

\section{Informational Politics and Digital Mapuche Media/Activism}

A key strategy for social and/or Indigenous movements with little resources is to create, support, and spread alternative information about their situation, both autonomously or aided by international actors. The efforts of the Zapatistas, in particular, in creating and proliferating alternative sources for information by focusing on their capacity to build informational (especially digital) networks have been analysed thoroughly (Bob 2005; Hayden 2002; Khasnabish 2008; 2013; Olesen 2005; Rovira 2009; Wolfson 2012). Yet whilst the informational politics of the Zapatistas succeeded in gaining international attention, the informational strategies of the resistance of Mapuche communities and organisations are still largely overlooked in that context.

Nevertheless, Mapuche organisations and communities from Wallmapu, with the support of their diasporic network and other actors, have been launching a series of (especially online) communication and informational platforms since the late 1990s. This section will focus first on how information is created and put into circulation and, second, how this information aims to raise awareness and sensitivity about the situation in Wallmapu. As an expression of contemporary Mapuche informational politics, I will discuss the example of digital Mapuche media and digital Mapuche activism and their new developments, problems, and contradictions.

Within my activist ethnography, I was able to closely experience and take part in how information within TMA is created from the source to the final report. The processes of how information is produced can be differentiated 
analytically without hierarchising its value or legitimation in a series of steps (Keck and Sikkink 1998, 18-22).

One step is the distribution of informal information through close and personal relationships between different actors. Stories are told on a face-toface basis, when someone who just visited Chile and Wallmapu brings back some insights of how he or she experienced the current situation in his or her immediate surroundings. Mapuche representatives who travel to Europe also share their stories not only in official talks but in informal conversations. Especially the meetings and demonstrations in solidarity with the Mapuche are used for this type of information sharing.

Today, informal information is distributed largely on social media sites like Facebook or Twitter, where people across the globe can access the personal stories of people they follow and upload pictures of a police raid or give testimonies about an incident. Central social media sites are those of representatives of Mapuche organisations or of werken of a community. Their sites often become alternative sources of information within TMA.

National media and the governmental perspective in Chile not only contribute to creating a distorted picture of the conflict in Wallmapu but also leave out important incidents and problems. Another type of information is targeted at uncovering and reporting on the issues that are left out. Domestically, two non-Mapuche organisations are crucial actors in this regard. These are the $\mathrm{INDH}^{11}{ }^{11}$ particularly the regional office in the Araucanía region, and the Observatorio Ciudadano (OC) ${ }^{12}$ in Temuco, who uncover and report viola-

11 The National Human Rights Institute has a mandate to promote and protect human rights in Chile in an independent and autonomous manner with a type A accreditation for human rights institutions bestowed by the UN. The INDH has three lines of action for the protection of human rights: condemnation of violations, imposing judicial sanctions, and observation and detailed reports. Since 2015, the INDH has had a regional office in Temuco for the Araucanía region, from where it has produced a series of documents, such as annual mission and thematic reports regarding the human rights situation of the Mapuche in the region (Federico Aguirre, interview with the author, March 2, 2016).

12 The Observatorio Ciudadano (Citizens' Observatory) investigates, promotes, and defends human rights. Though the $\mathrm{OC}$ once focused on the violation of human rights regarding the persecution and criminalisation of the Mapuche, today its main focus consists of counselling and supporting Mapuche communities and organisations, in particular in territorial conflicts with private companies or landowners. The work of the $\mathrm{OC}$ is thus guided by a holistic vision on territoriality, including not only land, but also water, wind, and natural resources, and supports cases where the territory of the Mapuche is 
tions of human rights against the Mapuche. Two important networks, composed of a large number of independent non-Mapuche and Mapuche journalists and activists, uncover and report information from Wallmapu, mostly relating to human rights violations and ecological justice. These are the media platforms Mapuexpress and the Red por la Defensa de los Territorios (RDT). ${ }^{13}$

Important international contributions to the TMA also include reports from rapporteurs who are prepared, funded, or supported by international organisations in collaboration with Mapuche organisations and/or intellectuals. These reports ${ }^{14}$ are another key instrument for denouncing violations of human rights and pressuring the Chilean government to respect the Indigenous rights based on ILO Convention 169 or the UN 2007 Declaration. Another international contribution to uncovering and reporting incidents are missions of human rights observations, like the ones organised by the regional branch of the GfbV in Germany. The observations are usually distributed amongst (Mapuche and non-Mapuche) activists of the NGO's network and eventually to other NGOs or groups. During their trips to Wallmapu, human rights observers (like Alex Mora, Rike, or myself) usually closely accompany one or more specific case wherein human rights have been violated and visit political Mapuche prisoners or communities in resistance.

Another type of information that is activated for TMA includes academic investigations produced within a considerable network of non-Mapuche and Mapuche scholars. These investigations contribute to the purposes and claims

being defended against tree monocultures, wind farms, or hydroelectric powerplants (Rubén Sanchez, interview with the author, March 1, 2016).

13 Network for the Defence of Territories.

14 The most important and widely cited reports are those of the Special Rapporteurs on Chile on the situation of human rights and fundamental freedoms of Indigenous people (Stavenhagen 2003), on the promotion and protection of human rights and fundamental freedoms whilst countering terrorism (Emmerson 2014), and on the rights to freedom of peaceful assembly and of association (Kiai 2016). Other reports that denounce human and Indigenous rights violations in Chile include an alternative report to the CERD by UNPO and organisations of the Mapuche diaspora (UNPO, FOLIL, and Asociación Tierra y Liberad para Arauco 2013), the reports on advances and challenges in Indigenous rights matters in Latin America (CEPAL 2014), reports on the impacts of environmental damage on Indigenous people (UNPO 2015), the human rights report by the US State Department (United States Department of State, Bureau of Democracy 2015), a yearly report by Amnesty International (Amnesty International 2016), and a report on police violence against Mapuche children and adolescents sent to the $\mathrm{CIDH}$ (Alianza Territorial Mapuche, Fundación Anide, and CEJIL 2016). 
of Mapuche organisations and communities by reinforcing discursive or political positions of the injustice frame. The scholars come from multiple disciplines and are based in Chilean or other universities. For example, natural science investigations, together with Mapuche communities and organisations, have collected scientific data about ecological destruction such as water scarcity, deforestation, or the impact of power plants powered by natural resources.

Finally, TMA counts on strategic partnerships with international media like newspapers, magazines, or online journals (Keck and Sikkink 1998, 22). Strategic media partners in Germany include, for example, the monthly magazine Informationsstelle Lateinamerika, ${ }^{15}$ the online journal amerika21, the press pool Nachrichtenpool Lateinamerika (NPLA), and the monthly journal Lateinamerika Nachrichten. ${ }^{16}$ Other strategic media partnerships encompass a much larger number of newspapers and magazines in different countries and languages.

In our first conversation, Vicente Painel, then-president of the Kvme Mogen cooperative, pins down the contribution of non-Mapuche actors in transnational advocacy: "Now I tell you, generally, it is pluralising information! Like, having different versions getting out there. There is more than one version" (Vicente Painel, interview with the author, February 20, 2016).

I adopt the notion of pluralising information to describe the need for circulating alternative information about the situation of the Mapuche transnationally by transforming their domestic colonial framing. It would also mean enforcing the circulation of heterogenous information from a multiplicity of sources beyond the Chilean nation-state and its domestic civil society. Pluralising information would contribute to challenging "the danger of the single story" (Adichie 2009) about the Mapuche by the Chilean government and domestic media.

A multiplicity of stories would have a decolonising effect on how the Mapuche are represented and ultimately treated. Following the logic of the cultural politics of autonomy, the idea of the pluralisation of information demands a heterogeneity of versions and information about a certain incident and implies a centrifugal logic, where news, reports, or testimonies are made accessible beyond the local realities of Wallmapu and Chile.

15 The Latin American Information Site, with the support of diasporic Mapuche and their network, edited a special issue about the Mapuche in 2016.

16 Latin America News. 
Pluralising information was also described as a main goal of the visit of a Mapuche delegation from communities in resistance in 2014 to Europe. Amina, who supported the tour, said that "foremost it was about doing public relations work, to somehow spread the topic also here in Germany, Europe" (interview with the author, November 27, 2015). Another effort in pluralising information is the translation of reports or incidents from the Spanishspeaking Mapuche media. Here, diasporic Mapuche and non-Mapuche actors can make an important contribution. Amanda, a supporter of the diasporic Mapuche foundation FOLIL in the Netherlands, explains that translating is crucial "because it is getting, you know, news out there, [...] making the people understand so they become aware." She goes on that "this has a trickledown effect [and] in any small way it is still pushing forward awareness" (interview with the author, July 5, 2016).

New technological resources and online media have boosted the possibility of pluralising information more quickly and on a larger scale. Alex Mora (interview with the author, November 28, 2015), active in advocacy and solidarity efforts since the early 2000 s, experienced a decrease in the repression of Mapuche communities by the time it was possible to "open information to everyone" through the Internet.

Describing the aim of these informational politics, many Mapuche and non-Mapuche interview partners alike use similar nuances to what can be translated as consciousness-raising. A Spanish term that has been used in interviews for raising consciousness is sensibilizar: making someone sensitive towards something. Creating sensitivity towards something goes beyond the political approach of transnational advocacy, relating to an affective labour (Gutiérrez Rodríguez 2010a) and a cognitive-feeling process ${ }^{17}$ (Fals-Borda 2009) in interpersonal encounters.

Mauricio Painefil, director of the Mapuche tourism project at Llaguepulli, describes at length the effort of raising sensitivity: many people who visit their community arrive with a "harmful and condescending perspective" of the Mapuche, considering them "violent," "lazy [people], who do not like to work, [are] dirty, and, after that, they told us that the Mapuche were drunks." As the struggle for territory became stronger and more articulated amongst the Mapuche society, today "they brand us as terrorists, in different and very nitive-feeling process. 
condescending terms" (interview with the author, March 10, 2016). He intervenes in these frames by creating awareness amongst their guests that "it is not like that. We were never a violent nation, by origin we were never a lazy nation and people, we were never drunks, and anything but terrorists." His claim to the tourists is that "we are not of that nature!" (Ibid.). Instead, he goes on:

[...] from our origin we have been a very respectful nation and the same way they [the ancestors] taught us that we need to respect biodiversity, nature, we need to respect mother earth, we need to respect the elderly, we need to respect even the least significant living being [...]. We come from that logic! We do not come from a logic that destroys, but from a logic that preserves, that protects, cares, and respects everything that lives together on the earth [...].(Ibid.)

Raising sensitivity and consciousness about his people thus means deconstructing and decolonising the hegemonic stereotypes about the Mapuche in Chile. It includes the right and the autonomy of the Mapuche to claim by themselves who they are and what they want. Rather than reinforcing an essentialised positive identity, raising sensitivity includes the claim to the multiple and heterogenous ways of being Mapuche in the world.

According to Frantz Fanon (2008), a racial and colonial social structure produces an "inferiority-complex" amongst the colonised population. In that context, decolonising awareness and consciousness means to "be able to take cognizance of a possibility of existence" and "once his [the colonised subject's] motivations have been brought into consciousness, [it] will be to put him in a position to choose action (or passivity) with respect to the real source of the conflict - that is, toward the social structures" (Fanon 2008, 74-75). This poses a major challenge for the possibilities and limitations of raising a decolonial consciousness and sensitivity within solidarity actions, because it would mean that non-Mapuche people would need to become aware of the social structures from which they inherently benefit. In that way, a decolonial consciousness within solidarity without acknowledging white privilege seems impossible.

The efforts in digital activism by Mapuche organisations, communities, and its diasporic network attracted little scholarly attention throughout recent decades, despite information and communication technologies (ICTs) having been part of their mobilisation repertoire since the late 1990s (Ramos Gutiér- 
rez 2014). Today, digital Mapuche activism ${ }^{18}$ is a fundamental aspect of the informational politics within transnational advocacy and international solidarity. Several expressions of Mapuche online activism, especially in the last decade, have become internationally known. These include Mapuche websites and digital activism through social media. The Internet has thus become a central "tool, not a cause, for social change" (Hill 2013, 14) for social movements and grassroot activists with little resources in recent decades. At the same time, it has been used by more powerful and resourceful actors, like governments, policy makers, or corporate media, to discredit or repress social mobilisation. The Internet is thus an important tool for TMA, aiding to externalise their demands and condemnations, pluralise perspectives, and raise sensitivity, as well being a new site for conflict and repression.

The rest of this section briefly presents some of the most noteworthy digital Mapuche media sites. The following sites do not only have a huge impact and outreach but also the most credibility and the best reputation amongst the Mapuche society and within transnational advocacy.

To begin with, there are Mapuche media collectives who publish mostly online articles, reports, condemnations, announcements of activities or declarations, and videos, radio programmes, and streams. ${ }^{19}$ Probably the most well-known site is Mapuexpress, an online news site that updates almost daily. It spreads news about Mapuche culture and politics in Wallmapu, with a focus on the defence of the Mapuche territories, the situation of political prisoners, and the violations of human rights. It also includes news of international, artistic, or ecological character. To date, ${ }^{20}$ Mapuexpress has more than 72,000 and Werken Noticias more than 175.000 likes on Facebook.

Second, some Mapuche communities in resistance have created their own online presence, mostly in the form of blogs. ${ }^{21}$ Typically, these blogs serve to spread information related to a particular community, aggressions by the military police, territorial recoveries, and the situation of the communities' political prisoners. For example, I witnessed that in the community of Temucuicui

Digital activism can be described as "activism campaigns with a goal of social or political change that use digital technology." (Joyce 2010, 7).

19 Among them Mapuexpress, Werken Noticias, Azkintuwe, Adkimvn-Cine y Comunicación Mapuche, and Radio Kurruf.

20 These numbers on digital Mapuche media sites are from November 2021.

21 For example, Lof Rankilko (http://rankilko.blogspot.com) and the autonomous community of Temucuicui (http://comunidadtemucuicui.blogspot.com) 
everyone has the right to publish information through their own social media accounts. This is interesting because it challenges the traditionally monopolised task of a community's werken and pluralises the communicative labour.

Third, mostly urban and institutionalised Mapuche organisations have their own online or social media presence, where they publish information related to their organisation, activities, and members. ${ }^{22}$ Interestingly, these organisations have considerably less reach than the Mapuche media sites. One collective nevertheless has an outstanding online impact. Kimeltuwe $e^{23}$ has more than 220,000 likes on Facebook and almost 17,000 followers in Twitter, which probably makes it the Facebook page with the greatest reach amongst Mapuche digital media and by far the largest online space in Mapuzugun.

The fourth category includes websites created by the Mapuche diaspora, mostly in Europe. ${ }^{24}$ It is noteworthy that they distribute information related to the Mapuche in languages other than Spanish. Already in 1997, Jorge Calbucura, a sociologist at the University of Uppsala in Sweden, created the website Nuke Mapu - Centro de Documentación Mapuche. ${ }^{25}$ Other websites of the Mapuche diaspora contain information related to befriended communities and organisations in Wallmapu, their repression and persecution, trials against Mapuche representatives, the circumstances of political prisoners and, most importantly, about the sociocultural and political activities of the diaspora in Europe. Another important tool of the Mapuche diaspora is the open and mostly Spanish-language werken-Newsletter, based in the Netherlands. ${ }^{26}$

It is also worth mentioning the lack of an online presence of other important organisations and communities, like the CTT, or printed Mapuche

\footnotetext{
22 For example, Wallmapuwen, AMCAM, Kimeltuwe, Kvme Mogen, and Fütawillimapu.

23 Kimeltuwe describes itself as a "visual educational project that seeks to contribute to the teaching and learning of the Mapuche language. The aim of the project is to share graphic and audio-visual material through different internet platforms" (Kimeltuwe 2018; my translation).

24 For example, Nuke Mapu, Mapuche International Link, FOLIL, and the Women's Coordinating Committee for a Free Wallmapu.

25 Nuke Mapu is mostly concerned with academic information and research related to Mapuche culture, politics, territory, and thinking. This space serves as an alternative platform, forum, and communication tool for the intellectual production amongst the Mapuche researchers, academics, and students who do not have access to academic journals or corporate media (Ramos Gutiérrez 2014, 12). the bulletins of the CME from the 1980 s (see footnote 17 in chapter 4).
} 
newspapers and their online presence, such as Azkintuwe, founded in 2003, or the Mapuche Times, founded in 2011, both by the Mapuche journalist Pedro Cayuqueo. All of these have disappeared in recent years.

However, digital Mapuche activism also takes place beyond these websites. Information today mostly circulates in a de- and polycentral way according to the logic of social media like Facebook, Twitter, and e-mail newsletters. They contribute to pluralising links to particular reports and articles, demands, and condemnations, which are subsequently shared domestically and transnationally. The distribution of this information is highly pluralised, decentralised, and heterogenous, instead of being limited to a number of official sources.

The idea of a digital Mapuche activism was adopted in 2017 during a meeting in Santiago de Chile of Mapuche organisations. Participants discussed the diffusion of the usage of ICTs amongst the Mapuche population and argued for disseminating and revitalising the digital usage of Mapuzugun. Digital Mapuche activism thus might encompass those digital efforts of Mapuche activists disseminating information in online sites, social media, chatrooms, video, or photo platforms related to the sociocultural and political issues concerning the Mapuche society in Wallmapu and beyond.

Digital Mapuche media and digital Mapuche activism were born from the necessity of having their own alternative means of communication, seek the pluralisation of news that otherwise would not gain public attention, promote political demands amongst the Mapuche society, and advocate for Indigenous and human rights and the revitalisation of their culture (Ramos Gutiérrez 2014, 17). Digital Mapuche activism is particularly characterised by the speed of how information and news are spread, a relatively high reliability, thorough documentation and research, its impact amongst the Mapuche society domestically and transnationally, and the relatively low cost of the (re)production of information.

Other central aspects of digital Mapuche activism are: constant updates of information and news by digital media sites, Mapuche and non-Mapuche, as the prime source; analysis of political events; the desire to autonomously publish and spread information by the Mapuche themselves; the constant reference to and usage of debates and information about related topics; and finally, the presence and usage of Mapuche images, photographs, designs, cartoons, memes, and drawings (Foerster and Vergara quoted in Ramos Gutiérrez 2014, 6-7). 
Several contemporary discussions and new developments concerning digital Mapuche media and activism deserve some attention. To begin with, I would like to challenge the critique that some Mapuche media sites reproduce a stereotypical, essentialised, and idealised image of the Mapuche society, particularly its communal and rural life (Ramos Gutiérrez 2014, 8). Instead, I would like to contend, referring to the cultural politics of autonomy as well as critical race and decolonial theory, that digital Mapuche media and activism manages to (re)gain intellectual authority over what counts as authentic.

What would prove more insightful would be a critical examination of (online) representations by non-Mapuche about the Mapuche. For example, at one point a new website, mapuexpress.net, not be confused with the media collective Mapuexpress, appeared. This other Mapuexpress* is an English-language website run by a white, middle-aged women, possibly from an Englishspeaking country, who does not give any information about her identity, motivation, interest, and political stance on the website. The website professes to give information about the Mapuche history and "many aspects of Mapuche nation" (Mapuexpress*, n.d.), does not engage with or refer to Mapuche-run websites, and is currently offline ever since. The "About Me" section reveals that this woman came to learn about the Mapuche during a journey to South America, but it is otherwise unclear what her relationship to them is.

The visual representations in the website are particularly interesting: whilst the host provides a profile picture of herself in an upper-class, bourgeoise style (a clean haircut, calm smile, a white shirt, and gold jewellery), Mapuche people are represented only as an anonymous collective, in fighting poses, screaming, and even bleeding, wearing their traditional clothes. In that way, whilst the website positively references the Mapuche, it does not escape colonial representation politics and in fact reproduces a colonial stereotype: On the one side, the Western individual appears as a calm and neutral subject with authority to write about a very heterogenous society based on one journey. On the other, there is a scattered and very emotional mass of Indigenous people, who do not speak for themselves. The website thus showcases a romanticised stereotype about the noble struggle of Indigenous people, ${ }^{27}$ exteriorising its own revolutionary desire in order to maintain the privileged position of apparent neutrality and objectivity. Besides that, it is curious that this website appropriates the name of maybe the most impor-

27 For a deeper discussion of this romanticised stereotype, see chapter six. 
tant Mapuche media site without referencing it. This might even sabotage people who search for Mapuexpress but end up on Mapuexpress*.

Another new development of digital Mapuche activism today is that it is not limited to a number of particular Mapuche-run websites. Rather, digital Mapuche activism today is a highly pluralised, decentralised, and heterogenous phenomenon, carried out by countless individuals with their smartphones and social media accounts.

In one way, this transfers the logic of the cultural politics of autonomy (rhizomatic de- and polycentrality) to the digital sphere and thereby transforms the traditional sociopolitical role of the Mapuche communicator, the werken. This position is highly prestigious and requires a close and trustful relationship with the longko ${ }^{28}$ and a great amount of intercultural and communicative competence (Kaltmeier 2004, 316-19). For example, after her imprisonment in early 2016, machi Francisca Linconao appointed Ingrid Conejeros, a young Mapuche woman born in Santiago de Chile, as her werken. She became werken not as a consequence of her position within a Mapuche community, but as a community outsider and by appointment. During the imprisonment, the werken's Facebook page became the prime source for information about the current situation of the machi and mobilisation efforts in Chile and beyond. Does this mean that the traditional role of the werken as a community-based position is jeopardised by the pluralisation and decentralisation through the utilisation of ICTs? Or does this development deepen the cultural politics of autonomy by democratising the position of the werken? Whatever direction this development takes, these questions might lead to challenging discussions within the Mapuche society.

Another interesting development is the comparatively small online presence of Mapuche communities and organisations compared to digital Mapuche media sites. Furthermore, older Mapuche organisations, like the CTT or the CAM, have either no or little presence in online media and platforms than more recently founded organisations, like Wallmapuwen or AMCAM. The communication strategy of the latter is clearly focused on the utilisation of ICTs, particularly social media (Mauricio Vergaras, interview with the author, February 25, 2016a).

Whilst the more senior Mapuche organisations like CTT and CAM have a small digital impact, some of the first Mapuche newspapers, like Azkintuwe and Mapuche Times, which were prominent in the early 2000s, have almost 
completely vanished and are not published anymore. This means that there is a clear shift from printed to digital Mapuche media.

Also, whilst previous investigations mentioned a relatively modest media output in Mapuzugun (Ramos Gutiérrez 2014, 6), the number of digital Mapuche activists and media sites publishing in Mapuzugun is increasing today. These manage to include both exclusively Mapuzugun and bilingual content. Especially the efforts of the Kimeltuwe collective stand out by maximising the content published in Mapuzugun and by shifting the focus on language education and cultural revitalisation. Compared to other Mapuche digital media, Victor Carilaf points out that "we only marginally engage with the struggle of the Mapuche, [...] because we believe that there are already enough websites" (interview with the author, February 23, 2016). Instead, their focus is on revitalising the language and making it more prominent as a spoken and active language within social media. They claim ICTs and social media as an absolutely legitimate and powerful tool, since "all trenches are valid to fortify our language and our culture" (Figure 3).

This is a transnationally visible and prominent effort in decolonising the monolingual dominance of the Spanish language and in transculturalising means of communication. Digital media and ICTs hereby contribute to (re)creating the Mapuche culture and social belonging through language (Slavsky 2007).

Ultimately, digital Mapuche media and digital Mapuche activism consolidate, deepen, and democratise the cultural politics of autonomy. This is because ICTs "allow to create a discourse, to create an image of how one wants to be seen by others, in this case the non-Mapuche, and in this way defining, based on one's own knowledge, what the Mapuche culture is" (Ramos Gutiérrez 2014, 5; my translation). In that way, these expressions are a form of "mass self-communication" as one crucial element of the communicative and networking efforts of contemporary de- and polycentral social and political movements and protests (Castells 2015, 256-62). ${ }^{29}$ These movements and the Internet now "share a specific culture, the culture of autonomy, the fundamental cultural matrix of contemporary societies" (Ibid., 258). This could mean that the usage of ICTs and digital media is not only an expression of the

These efforts involve a high level of connectivity and operate at a large scale due to their translocal and transnational connections. Castells discusses, for example, the Arab uprisings (the so-called Arab Spring), the indignadas movement in Spain, and Occupy Wall Street in the US. 
Figure 3. Kimeltuwe. 2016. "Küme antü rulpayaymün, kom pu che!"

\section{Itrokom weychawe pünel-fali witrapürantuafiel taiñ zungun ka taiñ az-mongen!}

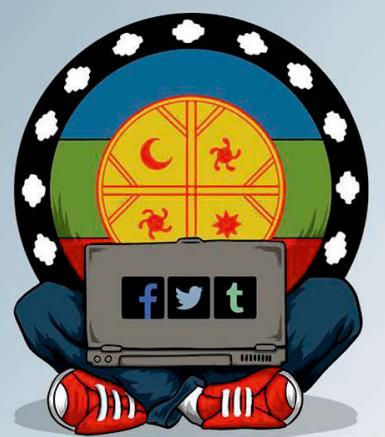

¡Todas las trincheras son válidas para fortalecer nuestra lengua y nuestra cultura!

f/kimeltuwe

Facebook, January 25, 2016. https://www.facebook.com/kimel tuwe. Screenshot by the author, taken January 25, 2016.

Mapuche society adopting and incorporating non-Mapuche elements (Kaltmeier 2004, 37-42); I want to push this argument further and claim that such cultural politics of autonomy might even be better equipped (than centralised organisations) to grasp the full potential of ICTs and digital media.

Despite this subversive and decolonial potential of digital Mapuche media and activism, this development is constrained and limited by some contextual-mostly political and socioeconomic-factors. Material limitations include the general reach and speed of the digital infrastructure provided by the state and private companies, the access and usage of applications, online platforms and social media, and finally the access to and distribution of devices like computers or smartphones (Joyce 2010, 2-4). On the other hand, external elements like "economic, social, and political factors determine whether 
and how people use this infrastructure" (Ibid., 4). Regarding the context of the access to and usage of the ICTs by the Mapuche society, researchers speak of a "digital gap," which mostly affects rural Mapuche communities (Garrido, Martínez Sánchez, and Solano-Fernández 2011; López-Vicent, Sánchez-Vera, and Solano-Fernández 2014). This digital gap is characterised by a lack of training and resources in the usage of ICTs. Another feature is the contrast between the generally wide distribution of computers and smartphones and restricted Internet access. ${ }^{30}$

There are also contextual factors that negatively impact the effectiveness of digital Mapuche activism which need to be understood within the general political context. For one, the criminalisation and repression of Mapuche mobilisation is expanded to the digital and online sphere. As a result, digital Mapuche media and activism is often confronted with digital warfare by powerful and resourceful actors.

One episode of this digital warfare took place in 2017: on September 20, the Chilean Carabineros and Policía de Investigaciones de Chile ${ }^{31}$ carried out a high-scale operation under the name 'Hurricane Operation' against several leaders of Mapuche organisations and communities. ${ }^{32}$ The raids and detentions were justified with reference to the Anti-Terrorist Jurisdiction and were carried out with a high level of police brutality, leading to the destruction of property in the communities. That same evening, a "great strike against the terrorism of the Mapuche" (Seiwerth 2018) was announced in the national media and the names, photos, and personal data of those captured were presented.

As evidence, the police forces presented intercepted conversations on messaging services like WhatsApp and Telegram between some of the captured leaders. In those chats they were apparently talking about committing arson attacks and smuggling guns from Argentina to Chile (Seiwerth 2018). These conversations seemed pretty frivolous and were mocked in Mapuche online spaces as 'fake news.'

A month and a half later, the case finally blew up when the state's attorney of Temuco, Luis Arroyo, acknowledged the existence of the falsified evidence

30 For example, broadband in rural communities is almost nonexistent and Internet access is limited to mobile Internet.

31 Police Investigation Unit and the Civil Police of Chile.

32 Amongst them Jaime Huenchullán and several of his brothers from the community of Temucuicui, as well as Hector Llaitul of the CAM. 
that led to the operation and the incarceration of these Mapuche leaders. This declaration was reinforced when intelligence officer Alex Smith and four members of the criminal laboratory in Temuco acknowledged the mechanism by which the evidence was faked. ${ }^{33}$ By 2018 , there was enough evidence to prove that with the 'Hurricane Operation' the Carabineros illegally intercepted the mobile phones and e-mails of Mapuche activists and their supporters, willingly falsified evidence by inventing fake intercepted messages between Mapuche leaders, and fabricated evidence using nonworking software tools (Sepúlveda and González 2018).

Another example of the digital warfare against digital Mapuche activism was a lawsuit in 2017 against Alfredo Seguel, member of Mapuexpress and the RDT. Alfredo Seguel had called out the involvement of the Mapuche consultant Andrés Antivil ${ }^{34}$ in several efforts of building hydroelectric power dams in the Araucanía region. He particularly criticised Antivil's role in the support of the construction of enterprises which threaten the territory and livelihood of several Mapuche communities. In a public statement of one community, published on Mapuexpress, Antivil was called a traitor to the Mapuche cause: yanakona. In July 2017, Antivil filed a lawsuit against Alfredo Seguel, accusing him of slander and injury in public statements, and demanded a compensation of approximately 11,000 USD (Parra 2017). Whilst Alfredo Seguel was declared not guilty, this case unleashed preoccupation amongst digital Mapuche media and activism about the intent to silence critical voices against such infrastructure projects.

During my activist ethnography in Europe and Chile, I was given several testimonies about intercepted, hacked, and maliciously reported social media sites of Mapuche communities and activists. For example, some actors of the Mapuche diaspora have been targeted on Facebook by conservative and rightwing accounts and have been accused of encouraging and fostering terrorism in the region.

Despite the digital gap and digital warfare, Mapuche media and activists are successfully contributing to the creation and pluralisation of informa-

33 These events finally led to the resignation of the general director of the Carabineros, Bruno Villalobos, and the institution's intelligence director, Conzalo Blu, as well as to legal steps that the incarcerated Mapuche leaders have been taking against the state since.

34 Antivil works as a forestry engineer, a consultant of the Inter-American Development Bank, and is president of the civil society council of the Chilean Ministry of Energy. 
tion domestically and transnationally. They thus challenge the very material constraints of a situation that threatens, sabotages, and structurally disadvantages them. The everyday usage of smartphones enables many (especially young) Mapuche community members to document and immediately denounce police raids or human rights violations. The smartphone became a tool of (personal and community) self-defence ${ }^{35}$ against transgressions by the police or other armed actors. With these tools "you cannot hide the reality anymore!" as Alex Mora (interview with the author, November 28, 2015) sums up. As a form of mass self-communication, even Mapuche community members with low resources can use these technologies to document every possibly harmful and threatening situation at any moment.

In summation, digital Mapuche media and activism have become powerful tools against the everyday repression in Wallmapu and for transnational pluralisation and consciousness-raising. But at the same time, they opened another (digital) front on which their resistance and struggle is contested by powerful and resourceful actors.

\section{Transnational Pressure: Symbolic, Leverage, and Accountability Politics}

TMA and international solidarity activate different tactics to exert pressure on target actors in order to make them accountable and create leverage. The advocacy's influence and pressure thus seek to challenge and transform institutional procedures whilst aiming at concrete changes in policies. They hereby target actors on an international level and governmental behaviour on a national, regional, or local level (Keck and Sikkink 1998, 26). And because of the rather unsuccessful attempts of Mapuche mobilisation to change Chilean policy and institutions in the 1990s, it has increasingly transnationalised itself. Through "transnational diffusion," Mapuche communities and organisations have "spread [...] similar forms of action and similar claims across borders" (Tarrow 2011, 235). These efforts are directed towards powerful target actors and a transnational civil society, seeking to change their perspective on the

35 Specifically, the Internet "protects the movement against the repression of their liberated physical spaces by maintaining communication among the people within the movement and with society at large in the long march of social change that is required to overcome institutionalized domination" (Castells 2015, 257-58). 
situation in Wallmapu, their discursive positions, as well as their political and economic decisions. The transnationally distributed information thus aims to create concrete changes in the form of "norm implementation, by pressuring target actors to adopt new policies, and by monitoring compliance with international standards" (Keck and Sikkink 1998, 3).

Within TMA, different forms of protest become transnationalised by the Mapuche and Chilean diaspora and transmitted to Europe. These protest forms are foremost characterised by disrupting the regular course of everyday life or routine of opponents through mostly symbolic actions (Tarrow 2011, 101). Most of these political strategies are contingent, limited to particular campaigns, and performed in a cyclical manner, for example in commemoration of a certain date. In those campaigns, particular groups and actors come together and form the networked structure of transnational advocacy and solidarity (Keck and Sikkink 1998, 6). The following section focuses on some episodes of such transnational and translocal campaigns that pressured target actors symbolically, created leverage, and held them accountable (Ibid., 16-25).

Political protests of TMA gain influence by invocating sets of symbols that are meaningful to the sociopolitical circumstances of a movement or to outside actors. Such symbolic politics have "the ability to call upon symbols, actions and stories that make sense of a situation for an audience that is frequently far away" (Ibid., 16). In the case of TMA, these kinds of symbolic politics are a powerful tool for addressing the injustice frame on a transnational and translocal scale.

A major symbol for the repression and structural discrimination of the Mapuche are Chilean institutions and governmental representatives. Thus, Chilean embassies and consulates are the prime target for demonstrations that are organised by the Mapuche diaspora and their solidarity network all over Europe. In 2016, I participated in a solemn vigil held at the Chilean consulate in Cologne, organised by the Mapuche regional group of the GfbV together with other solidarity activists. The occasion was the detention of several Mapuche leaders in April 2016 in the context of the Luchsinger-Mackay case. These solemn vigils, a typical protest tactic of the GfbV, are officially announced and take place on the street at the entrance of the consulate. Mapuche flags and banners are laid down on the street, held by activists, or fixed to trees or light posts. Activists from the Mapuche diaspora dress in traditional Mapuche clothes and generate attention by playing Mapuche instruments like the trutruka or kultrun. Banners and protest signs address the 
human rights violations in Chile, call out the politicians responsible, and demand freedom for the imprisoned Mapuche. During such vigils, petitions by the imprisoned Mapuche and their solidarity network are read in Spanish, the local language, and Mapuzugun. These vigils have a disruptive element by disturbing the work of the Chilean consulate, getting the attention of bystanders, and interrupting the flow of pedestrians on the sidewalk.

Figure 4. Solemn vigil in Cologne in 2016

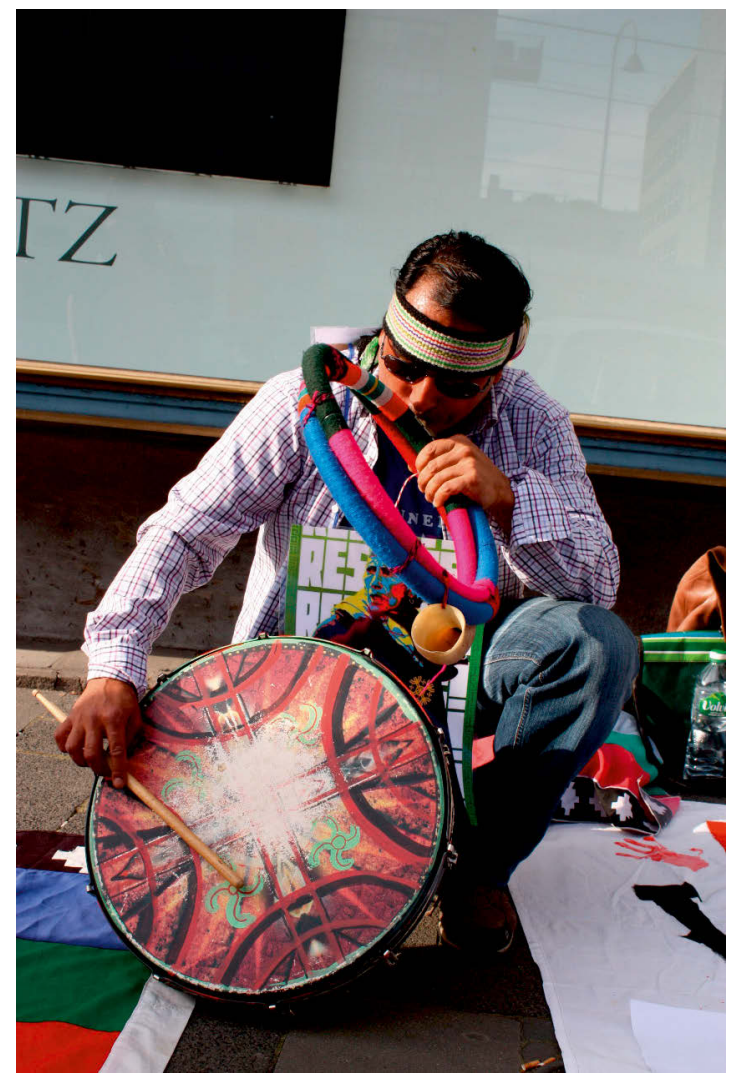

Photograph by the author.

Another type of disruptive political action is the so-called funa. The protest tactic funa (from the verb funar) has its origins in postdictatorial Chile. Human 
rights organisations began calling out alleged or known human rights offenders, perpetrators, or complicit politicians at their houses and workplaces. The funa's aim is to publicly denounce the responsible people for human rights violations and to interrupt their everyday lives. Consequences of these actions might be that the people who were called out stop showing up at their workplaces or move out of their homes (Oyander Clemens 2002).

Interestingly, the word funar stems from Mapuzugun and can be translated as 'to make or let something rot.' This protest tactic has been adopted by the Mapuche and Chilean diaspora in Europe not only to funar Chilean embassies and consulates but specifically to call out former Chilean President Michelle Bachelet in Europe for human and Indigenous rights violations by her government. Primarily during her last mandate from 2014-2018, Bachelet undertook several trips to Europe, where she was called out on several occasions, for example in Stockholm, Geneva, Cologne, and Leuven. The latter refers, as mentioned before, to Bachelet's visit to the CELAC Business Summit with the EU on 4 June 2015, whilst also being rewarded the Doctor honoris causa at the University of Leuven. ${ }^{36}$

The significance of this protest can hardly be overestimated, since a protest of that kind during an official act by the Chilean President, including direct eye-contact with the protesters, would not be and has not been possible up until then in Chile. Furthermore, the Mapuche women were a visible Mapuche presence in the audience, calling out the government policy. In Chile, the presence of Mapuche people during government acts is usually only accepted as a sign of apparently peaceful multiculturalism. The protest sparked a lot of international attention in media spaces, as well as in Chile. This protest counts as a clear success of disruptive politics, especially because it took place in Europe and the Mapuche activists were able to officially register for the act. In Chile such a protest would have been answered with severe repression and criminalisation.

Nevertheless, Chilean police officials, as part of the President's delegation, approached the three Mapuche women as they entered the hall, started

36 This funa was organised by the $\mathrm{CME}$, who in online statements criticised the situation of the political Mapuche prisoners in Chile, the militarisation of Wallmapu, the neoliberal model of exploitation of the region, the neglect of the ILO Convention 169, the insufficient territorial restitution towards the Mapuche, the neglect of the treaties of the Mapuche with the Chilean state, paternalistic politics, and the triple discrimination of Mapuche women (Mapuche NL 2015a; 2015b). 
Figure 5. Funa in Leuven

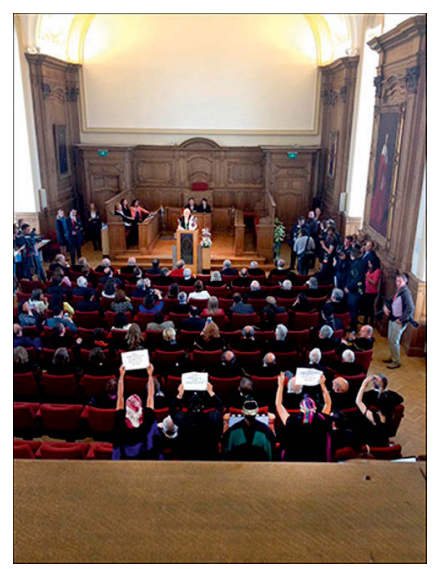

Mapuche NL 2015a. "Leuven: Protesta Durante Visita de Bachelet a Bélgica." 2015. https://mapuchenl.w ordpress.com/2015/06/07/protestadurante-visita-de-bachelet-a-belgic a/.

interrogating them, and threatened to call the Belgian police if they did not identify themselves. They further threatened the three women by suggesting that a police involvement would not be favourable to them. From the very beginning of the event, the policemen sat beside the activists and followed their movements closely. After the event, they escorted the three women to the exit, and they weren't allowed to take part in the reception afterwards (Bangert 2015).

Another example of symbolic protests within the solidarity and advocacy efforts in Europe was the tour of the Chilean military ship La Esmeralda in summer 2015, introduced in the previous chapter. In the protests against the ship's tour, they managed to amplify the injustice frame about the past human rights violations of the military dictatorship in Chile in order to address the human rights violations against the Mapuche in Chile today. They used an emblem which is a prestigious and allegedly innocent marker of the Chilean navy and is simultaneously a symbol for crimes against humanity committed 
during the Chilean dictatorship and amplified its chain of symbolic associations with the situation of the Mapuche.

In another set of events in 2014, activists from the Mapuche diaspora in Europe initiated a symbolic hunger strike in the cities of Cologne and Amsterdam. The context was the already ongoing hunger strike of five political Mapuche prisoners in Chile. ${ }^{37}$ Hunger strikes have become a last resort for many political Mapuche prisoners to demand a fair trial against the accusations by the Anti-Terrorist Jurisdiction, including the possibility of suspending detention until the trial or specific demands regarding the right to perform religious practices in detention. Usually, these demands are not met by the Chilean officials.

The symbolic adoption of this protest tactic by the Mapuche diaspora is not only an effective means to draw attention to the actual hunger strikes in Chile, but also translocalises specific protest tactics to the European arena, where political hunger strikes have become rather rare. This form of protest confronts local institutions and the public with a tactic that threatens the protesters' physical integrity and calls upon the urgency of their demands and the determination of their struggle. This hunger strike was symbolic since it only lasted a couple of days. Nevertheless, it had a disruptive character, as it irritated the local government and civil society, invoking and putting to action a protest tactic of ultima ratio.

Furthermore, public declarations of solidarity by celebrities symbolically pressure Chilean governmental institutions and the Chilean civil society. By signing petitions or making public statements in support of the Mapuche, they exert pressure to adopt a different kind of policy towards the Mapuche and to change their perspective in the conflict. These symbolic declarations of solidarity with Mapuche communities, organisations, and political prisoners come from different areas and include powerful, transnationally visible statements. ${ }^{38}$

37 The general aim of the hunger strike was to "express our solidarity with Mapuche political prisoners in Chile and denounce the actions of the Chilean authorities, so that the State anti-terrorism law be finally abrogated" (Mapuche NL 2014). They further expressed a series of more particular demands in reference to the situation of the five imprisoned Mapuche and ended their statement by issuing a set of demands to Chilean President Michelle Bachelet, her cabinet, the two legislative chambers, as well as all Chilean citizens.

38 Some examples are the declarations of solidarity by antiracist and feminist activist and scholar Angela Davis during her visit to Chile in 2016; postcolonial and decolonial 
All of these symbolic protests are directed against particular target actors within transnationally visible digital media spaces and are (mostly) carried out by activists of the Mapuche diaspora and their rhizomatic solidarity network in Europe. These protests amplify and extend the claims of the Mapuche by addressing them within already existing injustice frames or by making them heard through the voices of celebrities. Hereby, claims and demands of the Mapuche movement achieve a considerably larger audience and "attract otherwise uninterested individuals" (Snow et al. 2008, 258). Symbolic protests by the Mapuche diaspora like funas, solemn vigils, or hunger strikes appropriate public spaces in Europe and include Mapuche symbols, sounds, voices, clothing, and protest tactics.

These protests transculturalise such public spaces and transfer disruptive political action from Wallmapu to Europe. The occupation of space contributes to creating a sense of community and togetherness in the concrete political practice of the activists, reframing its symbolic meaning and power, and producing a political space in which freedom of expression and political deliberation are demanded and put into praxis (Castells 2015, 10-11).

Whilst these symbolic politics mostly pressure Chilean institutions and government representatives directly, other tactics are directed towards target actors beyond the constraints of the Chilean nation-state. These are, on the one hand, "leverage politics, or the ability to call upon powerful actors to affect a situation where weaker members of a network are unlikely to have influence" and, on the other, "accountability politics, or the effort to hold powerful actors to their previously stated policies or principles" (Keck and Sikkink 1998, 16). In the present case, leverage politics are efforts of Mapuche representatives from Wallmapu or in diaspora that address their situation and demands in supranational governmental bodies like the UN in Geneva, the European Union (EU), the International Court of Justice in The Hague, or particular encounters with or letters to actors of these institutions.

Several werken of the autonomous community of Temucuicui have travelled to Europe on various occasions to inform the Human Rights Council in

scholar Boaventura de Sousa Santos; the Argentinian writer and activist Raúl Zibechi; the Argentinian Nobel Prize winner Adolfo Pérez Esquivel; the Mapuche football player Jean Beausejour; internationally known music artists like Manu Chau, Calle 13, and Ana Tijoux; and the Peruvian actress Qorianka Kilcher. These solidarity declarations are mostly published within spaces of digital Mapuche activism and are shared on social media. 
Geneva about massive violations of human and Indigenous rights. ${ }^{39}$ There have also been interventions by Mapuche representatives within the UN Permanent Forum on Indigenous Rights in 2013 and letters presented to the Special Rapporteurs on Human Rights, James Anaya and Ben Emmerson, by the ATM, Hector Llaitúl of the CAM, and other Mapuche communities (Habersang and Ydígoras 2015, 133-38). Since 2011, there has been a 'Permanent Mapuche Mission' at the UN in Geneva, represented by Flor Calfunao, currently in exile in Switzerland, and Reynaldo Mariqueo. Their strategy is to use the space of the UN for the purposes of the Mapuche, establish a permanent link with UN organs, and make the work of the UN and its activities transparent amongst Mapuche organisations and communities (Ibid., 138-40).

Furthermore, in 2012 activists of the ATM occupied the UNICEF headquarters in Santiago de Chile to call attention to the ongoing human rights abuses against Mapuche children. Consequently, the representative of UNICEF in Chile, Tom Olsen, travelled to the Araucanía region and later issued a statement denouncing the excessive violence in the region against children, demanding the police forces adjust their actions according to international protocols of human rights, and insisting on a peaceful solution to the conflict (Ibid., 140-41).

Other examples of influencing institutional procedures include the International Conference on the Mapuche Treaties or Parliaments in The Hague in May 2015, organised by the CME. In that context, Mapuche organisations from Wallmapu and in diaspora "demand[ed] [...] the compliance of the treaties or parliaments agreed upon between the Chilean State and the Mapuche People" (Mapuche Coordination Europe 2015). In other instances, the cases of human rights violations against the Mapuche were brought successfully to the Inter-American Court of Human Rights (International Federation for Human Rights 2014).

In these examples, the demands were mostly framed within the master frame of human and Indigenous rights in order to create leverage on the Chilean state, particularly to comply with ILO Convention 169. Despite its official adoption by the Chilean state in 2008, its implementation can be described as "highly deficient" (Habersang and Ydígoras 2015, 266; my translation). Also, a planned Indigenous participation and consultation (as demanded by ILO Convention 169), initiated by former President Michelle

39 For example, Jorge Huenchullán (in 2011 and 2013) and Jaime Huenchullán (in 2012) both had the opportunity to speak in that forum. 
Bachelet, has attracted massive critique by sectors of the Mapuche movement and "due to the lack of representativity and participation, the consultation was declared as illegitimate and even illegal by Indigenous organisations" (Orellana 2016).

But even successful leverage politics can backfire on Wallmapu, Mapuche communities, and individuals. For example, Alina Rodenkirchen (2016) argues that the continued repression against machi Francisca Linconao after 2013 is the consequence of her winning a legal dispute against a Chilean company. In that dispute she successfully defended her rights as a religious authority guaranteed in the ILO Convention 169. Her legal success became "a precedent for whole of South America: a strong woman, who cannot be stopped by powerful institutions and fights for her rights" (Rodenkirchen 2016, 14; my translation). Nevertheless, her legal success (by referring to the master frame of human and Indigenous rights) made her a target. Whilst her case became internationally celebrated by Indigenous and human rights advocates, machi Francisca Linconao and her community continued to suffer from repression and persecution. This case thus contributes to other decolonial critiques of human and Indigenous rights approaches by making their colonial limitations and racialised biases visible. This is because for some actors, an international legal success can turn into a pyrrhic victory.

In other experiences, diasporic Mapuche activists have been the protagonists in creating leverage within supranational organisations. For example in 2016, Alina Rodenkirchen of the CME gave a speech at the European Parliament in Brussels about the structural (in that case, particularly the linguistic) discrimination of the Mapuche and their contemporary struggle to revitalise the usage of Mapuzugun. The event was organised by the UNPO in cooperation with the Federación Mapuche de Estudiantes (FEMAE) ${ }^{40}$ and the Wvñelfe Foundation (UNPO 2016).

In the same year, representatives of the Mapuche foundation FOLIL in the Netherlands participated in the fifteenth session of the United Nations Permanent Forum on Indigenous Issues at the UN in New York. The organisation received infrastructural and financial support by the GfbV from Germany and addressed topics like the human and Indigenous rights of the Mapuche, the revitalisation of Mapuche culture and language, and ecological justice in the region (Mapuche NL 2016). 
Transnational advocacy by non-Mapuche actors and organisations is less common but is also a factor of leverage politics. For instance, in 2016 the former German Federal President Joachim Gauck was on his way to a diplomatic visit to Chile. Before he left, the GfbV had sent a him letter asking him to promote a fair and equal dialogue between the Chilean government and the Mapuche. The letter also mentioned the individual case of Guido Carihuentru, who was visited by several of the organisation's human rights observers (GfbV 2016).

Leverage politics have become an important strategy of TMA to address human and Indigenous rights violations transnationally, with the hope that international and supranational actors and institutions contribute to a policy change in Chile. On the other hand, calling out powerful actors other than the Chilean government who can be made directly responsible has been a less favoured strategy. Amongst these accountable (transnational) actors are private companies and their investment in ecologically damaging projects, private landowners, as well as governments of mostly European countries, whose citizens have migrated to the South of Chile in the last century and played a crucial part in the colonisation of Mapuche territory.

There have been only two cases of protesting against and directly pressuring private companies that were held responsible and accountable. One of them is the Italian fashion company Benetton. In 1991, Benetton acquired approximately one million hectares of land in Southern Argentina-a territory which was conquered by the Argentinian military in the nineteenth century, leading to a genocide of the Mapuche population of Puelmapu. Today, Benetton is a major antagonist for many Mapuche communities and organisations in Argentina in their struggle for reclaiming their ancestral territory (Cregan 2016). Although this case has gained considerable international attention, up to date the advocacy efforts to hold Benetton accountable are (besides some symbolic protests) scarce.

In contrast, the IDNMP-especially the local group in Oslo-have been very active in pressuring the Norwegian company Statkraft to abstain from the construction of a hydroelectric powerplant on the Pilmaiquen river in the Mapuche community of Cañete. Although the Norwegian company has opened its doors to protesters and received a protest letter during a demonstration in Oslo in 2016 (OPAL Prensa 2016b), the construction of the powerplant is still planned.

Other transnational protest and advocacy tactics to create leverage and hold actors accountable include petitions, protest and support letters, soli- 
darity postcards, and signature lists. Such actions are mostly taken in the context of a particular case, for example, to support a political prisoner or in the case of ecologically hazardous infrastructure projects. However, these forms of protests are less common.

Pressuring international target actors has become a central strategy of TMA, especially since the 2000s. On the one hand, these efforts create symbolic pressure for Chilean institutions and representatives transnationally and, as a consequence, raise awareness and sensitivity within the domestic civil society. Similarly, they have already managed to create strong leverage within international and supranational institutions against the Chilean state. On the other hand, targeting and pressuring transnational private companies who are directly responsible for land-grabbing, ecological destruction, and the criminalisation of activists has not developed into a permanent and substantial tactic within transnational advocacy and solidarity.

\section{Fortifying Wallmapu: Against Handouts and Towards Economic Solidarity}

Whilst the first two strategies are basically directed from Wallmapu towards a transnational sphere, the following section addresses efforts of TMA in the opposite direction, focused at Mapuche communities and organisations. An important aspect of international solidarity has been the direct and material support of struggles in the Global South by actors in the Global North. These experiences include solidarity trips to the Global South and support via alphabetisation campaigns, community building, or other educational projects (so-called brigades, in the case of solidarity with Latin America), financial aid to ideologically affiliated groups, or selling products of peasant or Indigenous communities in the Global North.

Understanding solidarity exclusively in such terms is problematic, as it focuses on supportive acts carried out by mostly white and Western actors. Such a view would reproduce the stereotype about the active white saviour and the passive Other and recentre the former's agency. A perspective critical of race and colonial relations rather questions this distribution of roles and critically examines the concrete and material supportive acts from the Global North towards the Mapuche and their effects. At the same time, political transformation and success should not only be measured by institutional or legal change within the nation-state or supranational organisations, but 
according to the parameters of the society that is supposed to benefit from international solidarity and advocacy. ${ }^{41}$ This strategy of international solidarity thus needs to be challenged according to who are its beneficiaries. Are they the Mapuche communities and organisations that receive solidarity in different forms? Or are they the non-Mapuche solidarity actors who appear as white saviours and validate their privileges?

Acts of solidarity and advocacy that actually benefit the Mapuche society would need to fortify particular actors, groups, and their collective efforts. Fortifying relates to the Spanish verb fortalecer, which is used by Fernando Díaz to describe his experience of supporting Mapuche communities as a non-Mapuche Chilean citizen in a way that contributes to empowering and solidifying the communities' sociopolitical and cultural institutions (interview with the author, March 26, 2016). According to this idea, the efforts of non-Mapuche actors and organisations are scrutinised according to whether they fortify the communal structure as a basis on which sociopolitical and cultural change can be pushed forward by the community itself. Against this backdrop, the following section engages critically with financial support of and donations to Mapuche communities as a form of TMA.

Financial donations and charity are the easiest form of helping others, since they do not require further commitment or direct involvement. During my ethnography, I witnessed only a few projects that provide financial aid for communities and organisations in Wallmapu. ${ }^{42}$ The following pages present two of these projects, as well as an alternative of economic solidarity by the Mapuche cooperative Kvme Mogen.

One case study involves the German Christian aid organisation Adveniat, which originated in Germany's postwar period. In that time, a health and

41 This argument is inspired by Spivak's (2004) call for an education in and for the Clobal South in which the affected population designs and affirms their rights, humanity, and parameters. Coulthard (2014) also analyses the limitations of an approach that seeks recognition according to Western and colonial parameters.

42 For example, there have been some international calls to fund the Mapuche language camps organised by the FEMAE and the Wvñelfe Foundation in the struggle for the revitalisation of Mapuzugun (UNPO 2016). These calls were spread transnationally on social media. On my second fieldtrip to Chile, I had a chance to meet Rubén Collío, the husband of the murdered activist Macarenca Valdés. He told me that there have been collections organised by the IDNMP in Europe to fund a second and independent forensic examination to rule out the cause of death of his wife as suicide, which was determined in the first examination. 
hunger crisis struck Germany, and the Catholic and Lutheran churches in Latin America started collecting money for the German population. As a form of reciprocity, some German bishops in the 1960 s began to form an initiative to support the Catholic church in Latin America through financial and humanitarian aid. Adveniat was finally born as a consequence of the periodical collections for Latin America during Christmas. Today, Adveniat funds 2,442 projects in Latin America with a budget of approximately forty-one million euros. In Chile, Adveniat supports a total of fifty-six projects all over the country, with an average budget of 18,000 Euros per project in the period of 2015-2016 (Bischöfliche Aktion Adveniat e.V. 2017, 13). Three projects focused on Mapuche are funded by Adveniat in the cities of Santiago de Chile, Tirúa, and Temuco. I visited all of these during my fieldwork.

In Santiago de Chile, the Pastoral Mapuche ${ }^{43}$ came to existence out of the lack of an intercultural religious space for Christian Mapuche who migrated to the city over the course of the twentieth century. In 2007, Adveniat offered their financial support to a small group of Christian pastors associated with the Society of the Divine Word (SVD), who were already engaged in providing Christian spaces for intercultural encounters. Adveniat's financial aid is used to rent a small office, including a library, pay the salary of a secretary, organise meetings of Mapuche Christians in Chile and Argentina, summer courses, fund trips to international meetings for the staff, and to organise talks and conferences.

In the coastal city and parish of Tirúa, a relatively poor region of the Arauco province in Southern Chile, Adveniat has been financially supporting the Jesuit Mapuche Mission (JMM) since 2000. ${ }^{44}$ The work specifically funded by Adveniat comprises the mission's infrastructure, mobility, and the

43 On my first fieldtrip to Chile, I was able to have a group discussion with members of the Pastoral Mapuche, amongst them Germán Morales, Frida Erazo, Luís Rodríguez, and Martín (who did not introduce himself with his last name).

The JMM collaborates with and is integrated on a local level with other organisations, such as Hogar de Cristo, a nation-wide public Christian aid organisation with a focus on educational and health projects; the Asociación Indigena Relmu Witral, a weaving cooperative of more than one hundred Mapuche women in the region; the Fundación Licán, a platform by the JMM that provides scholarships for individuals, families, and lowresource communities; and finally the local office for the protection of children's and adolescents' rights, OPD Pewma Lavkenche. Since 2010, the JMM has also had a special focus on the reconstruction of community structures due to the seaquake that hit the region in the same year (Juan Fuenzálida, interview with the author, March 12, 2016). 
financing of scholarships. ${ }^{45}$ The JMM is in close contact with Christian and non-Christian sectors of the local Mapuche society and supports the sociopolitical, spiritual, and cultural efforts of a considerable number of communities. In recent years, the mission also began to concentrate its efforts on documenting and criticising the militarisation in the region, the violation of human rights, and the ecological injustices (Juan Fuenzálida, interview with the author, March 12, 2016). Instead of having concrete aims, Juan Fuenzálida prefers to highlight their work as "having a presence in the Mapuche world." The work dynamic is described as one of an "insertion," where the non-Mapuche priests intervene in a direct and everyday basis in the communities' struggles and realities (Ibid.).

In the small town of Quepe at the outskirts of Temuco, Adveniat has been funding the NGO Justicia, Paz, e Integridad de la creación en La Araucanía (JUPIC) $^{46}$ since 2000, which is part of the SVD and dissociated from the Chilean Catholic church. Fernando Díaz, the organisation's priest and director, notes that the financial support of Adveniat does not have an immediate material aim, but rather supports JUPIC in the "reconstruction of the social fabric, the fortifying of identity, of the culture, and of the interreligious dialogue between the Mapuche and the Christian world" (interview with the author, March 26, 2016). JUPIC consists of an intercultural team of three Mapuche and four non-Mapuche on a voluntary basis. Their line of work consists of "basically accompanying communities" (Fernando Díaz, interview with the author, March 26, 2016) in processes of cultural recovery, the strengthening of their spirituality, and of supporting cases of human rights violations. Adveniat particularly funds activities of JUPIC, such as visits to communities; the organisation of workshops, encounters, and seminars; domestic and international travel; and others (Ibid.).

The donations of Adveniat thus do not go directly to Mapuche communities and organisations, but rather provide the economic basis for the work of these three organisations. By describing their efforts as accompanying communities or inserting themselves in the Mapuche community, they point to a specific conception of solidarity work as the effort to establish intercultural and interpersonal relations of solidarity between the non-Mapuche and Mapuche world in the local context on an everyday basis.

45 The territory of the mission's intervention is quite extensive and requires covering more than 4,000 kilometres per month.

46 Justice, Peace, and Integrity of Creation in the Araucanía. 
In collaboration with an NGO from Europe and a former Mapuche mayor, Matías, as well as non-Mapuche researchers based in Chile, German activist Eva developed a microfinance project based on donations through crowdfunding with three other activists from Europe. ${ }^{47}$ This project targeted a parish with a large Mapuche population with the aim of financing solar panel equipment for electricity, productivity-enhancing tools for the particular activities of the participating households, and training for the installation, use, and maintenance of the devices, as well as for micro-entrepreneurial activities. In 2015, the researchers, together with Matías, invited the local Mapuche communities to the first workshop, where both the possible participants and recipients of the project were present.

During my interview with Eva, she told me that there was a need for more information about the Mapuche beneficiaries' activities and socioeconomic situation to implement the next steps of the project. In the interview, I offered to visit the parish and to collect this information for her, as I could use this ethnographic experience for my own research. During my first fieldtrip to Wallmapu, I contacted Matías, who provided me with a list of the possible beneficiaries of the project and organised my visit to the parish. There, I was received by his brother Cristián, who was my guide for the next three days and took me to visit seventeen of the possible participants of the project. ${ }^{48} \mathrm{I}$ also asked questions related to my research interest, for example about their perception of this kind of support, the transparency of the project, possible critiques, as well as alternative ideas for international support.

After my visit, I shared the information with Eva, who then organised it and uploaded some of my pictures on the project blog. Since then, I have been

\footnotetext{
47 All names in the context of this project have been changed.

48 The questions I was instructed to ask included general information about the household and family, their entrepreneurial activities, and the access to infrastructural supply for water and electricity. I was also asked by Eva to take pictures of the participants and their households and workspaces in order to put them on the project blog. Before the interviews, I was introduced by Cristián not as a collaborator or partner of the project, but as an independent researcher and human rights observer, who was doing the project coordinators a favour. I was very well received in every household and everyone was expecting me at the agreed upon time. Cenerally, they made a highly motivated impression and had their products, such as woven goods, merken (smoked chili powder), or woodwork, neatly laid out for presentation and were happy to show us the workspace and their production process. Every visit took approximately an hour and the conversations were saved digitally.
} 
visiting the project blog regularly, but the pictures and individual information about the beneficiaries, as well as the donation section, have disappeared. In our last conversation, Eva had mentioned that the project was on hold due to internal organisational impediments.

Shortly before my first fieldtrip to Wallmapu in 2016, Rayen Kvyeh had suffered an arson attack, in which her house almost completely burnt down to the ground. Fortunately, Rayen remained (physically) unharmed. During my visit, other solidarity activists proposed to collect money during her forthcoming trip to Europe. She vehemently refused because she "has a healthy mind and my hands to work, and with that I can make some money." According to her, "the Mapuche are fairly dignified [and that] is part of human dignity." From this it follows that "we do not ask for a handout" and "you are not going to see a Mapuche asking for a handout because for that we have our mind, our body, and our hands to work" (Rayen Kvyeh, interview with the author, March 1, 2016).

Jumping off from her sharp critique and rejection of (monetary) donations, the last part of this section critically discusses the issues regarding financial support through donations or funding towards the Mapuche by nonMapuche actors and organisations. The high level of poverty and limited access to state and private supply systems for water or electricity put (especially rural) Mapuche communities in a vulnerable situation. Mapuche communities and organisations have been reaching out since the 1980s and '9os to state institutions ${ }^{49}$ in order to gain access to their ancestral land or get funding for micro-entrepreneurial efforts. Both Matías and Cristián explain that the main reasons for reaching out to international funding campaigns are general mistrust, bureaucratic constraints, and the lack of success of Mapuche communities in applying to national funding agencies (Matías, interview with the author, March 28, 2016; Cristián, interview with the author, March 8, 2016).

But whether the funding is domestic or international does not change the fact that donations or funding might interfere with the local political structures. Matías, as a former mayor, put his symbolic and political capital at stake to support Eva's project. Also, when I visited the project, he was about to run for another term. To organise and coordinate a microfinance project that might fail could become a risk for him and his reputation. On

49 For example, The Chilean National Fund for Scientific and Technological Development (FONDECYT) or the CONADI. 
the other hand, the participation of the possible beneficiaries was exclusively mediated by Matías himself; these were mostly people socially or politically affiliated with him—some were even direct family members. Although Matías and Cristian emphasise the fact that only the "most advanced" were selected for the project, the question of whether or not local paternalistic structures are reinforced in this project remains open.

On another level, it seemed to me that the project was planned and organised exclusively from the outside and not by the Mapuche communities themselves. Eva explains that she "looked at the problems," "thought about what could be done," and "found [...] the solution" (interview with the author, December 1, 2015a). Eva's agency is thus at the centre of analysing the communities' problems as well as identifying possible solutions. Still, she puts emphasis on the need of including the local community in designing the project (Ibid.). There is thus a clear contradiction between her discourse and the organisation of the project. Do the non-Mapuche people really have the will to listen to the community's problems, ideas, or solutions? Or does the claim to include the local community rather serve to legitimise the intervention and to disguise a paternalistic project as participatory and inclusive?

Another problematic aspect of both case studies is their lack of transparency. In the case of Eva's project, the possible beneficiaries had little to no knowledge about the non-Mapuche actors, like Eva and the NGO in Europe, their motivations, or the role of the facilitators (Matías and Cristián). Also, the conditions of the microcredits, the amount, time period, credit rate, and repayment obligation were unknown. This was confirmed as a critical aspect of the project by Matías (interview with the author, March 28, 2016).

The three projects funded by Adveniat also lack transparency. Juan Fuenzálida was caught off guard with the questions regarding the transparency of the origin of their financial resources but was grateful for the intervention. In his answer, he reflects about the benefits of communicating the support of Adveniat more openly with the Mapuche communities they work with. He explains that on the one hand, it is a question of responsibility and accountability and, on the other, this could contribute to a feeling of being "accompanied" by international actors. On the contrary, he continues reasoning that holding back this information would patronise the Mapuche communities (Juan Fuenzálida, interview with the author, March 12, 2016).

The questions about the project's transparency led to wider discussions with my interview partners about the benefits and risks of financial funding and donations to the Mapuche society. The experiences of one non-Mapuche 
solidarity activist from Germany further inspired this conversation. Amina (interview with the author, November 27, 2015) had visited a Mapuche community in resistance in order to prepare a solidarity trip to Europe for some of its representatives. During her visit, a rumour inside the community spread that she was giving money to these representatives. The rumour then went on to say that they did not use the money the way the community had wanted. Finally, this led to internal division in the community and even a fight between these representatives and a political prisoner from the community. Amina assured me that she actually never gave them any money and suspects that her presence accelerated already existing divisions. For her, the rumour started just because "they saw us whilst we were walking through the community" (Amina, interview with the author, November 27, 2015).

Based on that and other experiences, whilst preparing my first fieldtrip to Chile, some activists of the Mapuche diaspora warned me about the possible effects of my presence in a Mapuche community. They told me that just being seen with a particular person could reinforce or introduce conflicts in the community. This was explained by the fact that a white, European-looking body represents access to financial support or certain benefits from the outside. The community would wonder why that person is accompanying the outsider, if not in exchange for something. It is thus not the funding in itself that represents a risk for the community, but the mere presence of a nonMapuche outsider. According to the Mapuche logic of reciprocity, the Mapuche host must receive something in exchange from his or her guest(s). It follows that the Mapuche host has been corrupted by the outsider and must be sanctioned. In that way, whiteness and the presence of a white body become an immediate threat to a community's social cohesion.

Other conversations also discussed the risk of introducing and reinforcing inequalities in the communities through financial support, eventually leading to immovable internal conflicts or divisions. For example, neo-extractivist companies have attempted to buy the communities' support for their projects, introducing or reinforcing political and social frictions (Isabel Cañet, interview with the author, February 24, 2016; Cristián, interview with the author, March 8, 2016; Luis and Nadia Painefil, interview with the author, March 10, 2016; Fernando Díaz, interview with the author, March 26, 2016).

But it is not only the direct economic interventions which may cause internal friction in communities; the symbolic closeness of non-Mapuche outsiders and Mapuche community members, leaders, or families alone can cause problems. For example, when the JMM started their work in Tirúa, 
they were provided a space to build their house and a small chapel on a Mapuche family's territory. At the beginning, "there was a lot of distrust and envy" and other Mapuche families thought they were going to take their land soon, hiding their "real agenda." As a consequence, the Mapuche family who had offered their land was alienated by the rest of the community (Juan Fuenzálida, interview with the author, March 12, 2016). Thus, whilst the reasons for such internal friction might not always be transparent, it is clear that the intervention and presence of non-Mapuche outsiders can have a concrete effect on the community's social cohesion.

These experiences show that financial support, funding, or donations must be sensitive to and respect the cultural politics of autonomy of the Mapuche. Funding might reinforce paternalistic structures and hierarchies in the communities, further strengthened by the lack of transparency. As Luis Painefil from the community of Llaguepulli explains, there is a need for "always communicating with the community, with the people" because "here in the community [...] there is an organisation" (interview with the author, March 10, 2016). He also highlights the importance of talking directly to the community through their assemblies. Support from the outside must thus respect and be sensitive to the community's internal mechanisms of deliberation and transparency-building (for example, through the roles of the longko and werken).

This demands to understand and to respect the relations of reciprocity within Mapuche society-because the same logic applies to how Mapuche communities and organisations relate to non-Mapuche organisations and actors. Fernando Díaz has experienced how the international-in contrast to the domestic-support does not aim to "co-opt the [internal] decisions." For him, the "networks of reciprocity are crucial for the international support to flow without destabilising the [sociopolitical] decisions" (Fernando Díaz, interview with the author, March 26, 2016). From that perspective, international solidarity and advocacy efforts are only effective and supportive as long as they do not destabilise the internal sociopolitical organisation of a Mapuche community and their internal relations of reciprocity. Following this idea, it is possible to understand what the idea of fortifying the Mapuche society through international solidarity and advocacy would mean.

In addition to the two case studies that aimed to support the Mapuche society through funding and donations, sectors of the Mapuche society are developing alternatives of economic solidarity which can be joined by non-Mapuche 
actors. Economic solidarity describes a theoretical and practical alternative of economic reciprocity, redistribution, and commonality that counters existing relations of domination and exploitation within society and between society and nature (Marañon Pimentel 2012b). Examples of international economic solidarity between the Global South and North are, for example, commercial networks that challenge capitalist and neoliberal mechanisms within trade relations. ${ }^{50}$ So what are the alternatives for economic solidarity within Mapuche society and are there similar experiences of economic solidarity between the Mapuche and the Global North?

I have come across only a few select experiences of Mapuche communities and organisations attempting to sell particular products within the transnational solidarity network. However, there is interest in creating these opportunities. For example, I was told that some merken producers in Temucuicui are interested in selling their semi-professionally designed products internationally. Also, Vicente Painel from the Kvme Mogen cooperative told me about the possibility of selling goods, foremost handicraft made of woodwork by the Mapuche political prisoners in Temuco, through the transnational solidarity network.

In contrast, commercialising Mapuche products internationally occurs mostly on a small and interpersonal scale within solidarity networks. Here, international activists buy products (handicraft like Mapuche jewellery or woven goods; natural products like merken or herbs) from producers they have a personal, trusting relationship with and sell these products in the intermediate context of solidarity activities in Europe, for example during demonstrations or talks. However, there are no formalised networks of economic solidarity that are able to move a large quantity of products with a larger outreach.

Rather different to the logic of the two case studies, the Mapuche cooperative Kvme Mogen has developed another vision for economic solidarity to support their society. In my two fieldtrips to Wallmapu, I got to know the activists and work of Kvme Mogen, based in the city of Temuco, well. In 2016, the cooperative had approximately 200 associates, Mapuche and non-Mapuche alike. ${ }^{51}$

50 One famous example of this is the commercialisation of coffee, as well as other goods, produced in Zapatista farming cooperatives and communities in resistance on the basis of solidarity and nonprofit trade with the Global North. larger amount of money in the cooperative, as long as it does not exceed $10 \%$ of the total capital of the cooperative. The saving and credit rates are 2 percent, amongst the lowest rates in Chile. Kume Mogen is legally a cooperative and by law is not allowed to 
The general aim of the cooperative is the "economic liberation" ( Painel quoted in Pérez Guerra 2016; my translation) of the Mapuche society as a colonised, dominated, and exploited part of Chilean society.

For this purpose, they have updated Mapuche cosmology and philosophy into contemporary economic endeavours by translating traditional Mapuche notions like keyuwvn (to work amongst everyone/as a community), mingako (collective work in the rural community), and trafkintu (fair and equal exchange). The founders saw an opportunity in the legal format of a cooperative, which respects and gives room for these notions (Ibid.). Thus, the only condition to become a member is to adhere to the ethical principles of the Mapuche, the az mapu (Vicente Painel, interview with the author, February 20, 2016), so both Mapuche and non-Mapuche can become members.

The aim of the cooperative is to challenge the neoliberal dependency amongst the Mapuche society on the private credit system in Chile, to fund small-scale Mapuche and non-Mapuche entrepreneurs, and contribute to instilling an ethic of saving amongst the Mapuche society. They have also used their capital to, for example, support the legal defence of Guido Carihuentru in 2016 (Vicente Painel, interview with the author, February 20, 2016). More recently, the cooperative has begun to sell the woodwork and artwork of Mapuche political prisoners.

Besides these material aims, another purpose of Kvme Mogen is to challenge the neoliberal subjectivation of the Chilean and Mapuche society in order to reconstruct social relations of reciprocity amongst the Mapuche. Gloria Marivil, member of the board of directors, highlights the importance of (re)building community amongst the associates, not only in economic, but primarily in social terms: "those to whom you lend money are part of this community" (Gloria Marivil, interview with the author, February 23, 2016). In that way, the activities of Kvme Mogen aim to "recover the trust, recover our economies by recognising our informal economies" (Ibid.). Based on shared trust and communal linkage, the cooperative seeks to reconstruct the social fabric of its associates, similar to what has been described as mechanic solidarity.

Reconstructing that "culture of mutual support" engages with the historical memory of the Mapuche society in reference to community or family nar-

make a profit. The gains of the cooperative have to be distributed amongst all members and each member has one vote in the annual general assembly (Vicente Painel, interview with the author, February 20, 2016). 
rations about the ancestral ways of working together (Gloria Marivil, interview with the author, February 23, 2016). Kvme Mogen transfers this historical memory to the arena of financial and monetary cooperation by expanding and translating the idea of the mingako. Thus, the work dynamic of the cooperative is sensitive to the need to not only eradicate relations of domination and exploitation in the sphere of production, but also within the sphere of circulation and its social effects. ${ }^{52}$ Thus, efforts like the ones of Kvme Mogen are based on and reconstruct the multidimensional cultural politics of autonomy by recreating social and communal networks, relations of reciprocity, and social relations of proximity through mutual financial aid.

Consequently, the role of international solidarity becomes rather marginal. There are a few international associates of the cooperative that are non-Mapuche and non-Chilean who regularly live abroad. In the same way as local associates, they have to adhere to the principles of the az mapu (Vicente Painel, interview with the author, February 20, 2016). Nonetheless, international associates have a high credibility within the cooperative because of a considerable strong tradition of cooperatives in Europe. Similarly, they contribute to the stronger visibility and credibility of the cooperative transnationally and domestically (Gloria Marivil, interview with the author, February 23, 2016). Transnational relations take place in the form of mutual visits by activists of cooperatives in Europe or members of the board of directors of Kvme Mogen. The main purpose of such encounters is to exchange experiences of economic solidarity and outline the possibilities of closer cooperation, for example through international agreements (Ibid.)

This means that relations of solidarity can be created only on horizontal and equal terms. At the same time, there is a need to get to know someone closely before he or she is accepted as a member of the cooperative. This is because becoming a member of Kvme Mogen is a "a conscious process" (Vicente

52 A critique of economic solidarity has been that the products of decolonised and fair economies ultimately end up in conventional profit-based markets. This critique further reveals the need for economic circuits of solidarity, "understood as the physical and financial flows that are established to produce goods and to satisfy basic needs under relations of reciprocity" (Marañon Pimentel 2012a, 147; my translation). An economic solidarity, understood in that way, thus aims to decolonise and dehierarchise a whole network of social relations and conditions and, in the context of Latin America, contributes to the struggle for food sovereignty, territoriality, space, agricultural ecology, reciprocity, ecological-economic efficiency, collective family property, and collective organisation (Ibid., 148). 
Painel, interview with the author, February 20, 2016). Thus, there is no possibility to, for example, just buy the cooperative's products or donate money. Rather, to engage in solidarity with the cooperative means to take part in the networks of economic solidarity on a local level, including its social, ideological, and cosmological dimensions. This includes a much more profound commitment than donating money or buying products. Whilst the latter follows an individualised logic of (organic) solidarity that absolves itself of a social commitment through payment, the former seeks to leave a debt open-as part of a logic of (mechanic) solidarity-and thus reproduces the need for social interaction and relations.

\section{Mapuchising Advocacy: Transcultural Dialogues and Translations}

"Having a dialogue" or "a conversation" have been articulated as a central aspect of solidarity work, particularly by Mapuche interlocutors. ${ }^{53}$ Such types of dialogues or conversations might serve to describe another crucial strategy of transnational advocacy and international solidarity, especially between Mapuche and non-Mapuche actors. Following these statements, I interpret the notion of having a dialogue/conversation as a cultural strategy of transcultural translation within TMA based on the cultural politics of autonomy.

Transnational advocacy and international solidarity bring Mapuche and non-Mapuche societies in contact with each other within and beyond Chile. They connect the Mapuche and non-Mapuche worlds and establish encounters for negotiating and transforming sociocultural meanings, symbols, identities, and concepts. Cuban intellectual Fernando Ortiz has developed the notion of transculturalisation in order to label "a process of cultural intercourse and exchange, a circulation of practices that creates a constant interweaving of symbolic forms and empirical activities amongst the different cultures that interact with one another" (Lionnet 1993, 103-4). Furthermore, "transculturalisation defines the transformation of culture through the impact of different historical legacies on cultural exchange" but "is not an outcome of harmoniously living together. Rather, it emerges from a myriad historical struggles

53 For example, in the following interviews: Radio Mapuche 2015; Alex Mora, interview with the author, November 28, 2015; The Hague, group discussion, May 5, 2015; Cristián, interview with the author, March 8, 2016; María Teresa Loncón, interview with the author, March 3, 2016. 
and negotiations [...]" (Gutiérrez Rodríguez 2010b, 116). In this way, the idea of transculturalisation is helpful for understanding the reciprocal, processual, multidirectional, and open cultural exchanges and transformations between Mapuche and non-Mapuche within solidarity action. It allows to focus on (post)colonial, racialised power differences and privileges, the conflictive and contained representational politics, and the multilayered historical legacies that are activated in the present context.

In the present case, for example, Jaime Huenchullán emphasises that the Mapuche have always been a "people very open to dialogue" (interview with the author, March 20, 2016). To him, their willingness to have dialogues and conversations with non-Mapuche has been a historically constant characteristic of his society. In a similar vein, Mauricio Vergaras (interview with the author, February 25, 2016a) explains the disposition of the Mapuche society to dialogue as historically rooted in the Mapuche culture.

Consequently, the historically and cosmologically rooted notions of the dialogue as a central cultural technique of the Mapuche are updated for contemporary transcultural relations within encounters of advocacy and solidarity. To begin with, the importance of conversational practices within Mapuche culture is visible on a small-scale level through the practice of the matetun, the collective drinking of mate tea, which "is characterized by gregarious, relaxed, affectionate, and empathic gatherings that involve discursive practices" (Becerra et. al. 2017, 13-14). Further, the notion and function of the dialogue is described by the Mapuzugun term ragiñelwe, translated as 'a space of the middle.' Ragiñelwe is "a cultural agent, whose function is to mediate between the affected parts," for example "between persons, where a certain type of disencounter ${ }^{54}$ [leads] to a certain degree of unbalance" (COTAM 2003, 1166; my translation). The institution of the ragiñelwe initiates a dialogue between the affected parties in order to re-establish the balance. This disposition to have a dialogue is also present, for example, in the sociopolitical institution of the trawvn, a space and moment of self-organised encounters involving dialogues, open deliberation, and agreements (Nahuelpan 2016, 114). Also, within the institution of the koyang, which was later translated as the parliaments and encounters between the Mapuche and Spaniards, the dialogue between

54 'Disencounter' is a very literal translation of the Spanish term 'desencuentro,' which refers to a failed encounter between two or more persons that could lead to a disagreement or fight. 
distinguished representative of each society in order to diplomatically resolve a conflict is important (Contreras Painemal 2010, 52-55).

The disposition to dialogue is further activated to differentiate Mapuche organisations and communities from the Chilean state. Here, the government officials are described by their unwillingness to have an open dialogue between equals on a horizontal basis (Mauricio Vergaras, interview with the author, February 25, 2016a; Radio Mapuche 2015). In contrast, the need for dialogic mechanisms to resolve the conflict in Wallmapu has been further addressed within the reports of UN Rapporteurs (Stavenhagen 2003, 20).

By emphasising their openness to dialogue, transnational advocacy and international solidarity aims to shift the framing of the supposed violent and belligerent character of the Mapuche society and highlight their capacity for transcultural communication and translation. This capacity is articulated as a specific political strategy rooted in cosmological understandings about institutionalised spaces of deliberation, exchange, and ultimately transcultural interaction. This cultural strategy thus Mapuchises transnational advocacy.

Translations are a key feature of transnational social and advocacy movements (Keck and Sikkink 1998; Tarrow 2011) and include complex cultural processes of transculturalisation and transnationalisation (Bachmann-Medick 2016; Gutiérrez Rodríguez 2006; Langenohl 2015). In such a perspective, "the focus moves towards specific processes of translation as well as towards differences, ruptures and un-translatable moments in the global circulation of theories, concepts, categories and terminologies" (Bachmann-Medick 2016, 30). Translation within TMA is foremost a political operation, through which claims, ideas, and worldviews are translated and translocalised into different cultural and linguistic contexts. Certain structural and individual experiences of injustice are thus selected, translated, and finally popularised. Actors of TMA contribute to processes of translation as part of their particularly situated "political-manipulative strategy, as a specific practice of power or even violence, but also as an important strategy for narrative legitimisations of war and conflict" (Ibid., 33).

The political purpose of these translation strategies in the present case is to build up support and sympathy with the struggle of Mapuche organisations and communities, as well as indignation about the injustices they face. But these strategies do not produce a perfect, one-to-one translatability of the different sociohistorical, political, epistemological, cosmological, and cultural contexts between Wallmapu and transnational spaces. Rather, these translation strategies need to be understood as processes "in which ambivalent social 
and cultural positions are negotiated. Thus translation procures understanding at the same time that it points to the potentiality of un-translatability" (Gutiérrez Rodríguez 2006). The following chapter will focus with more attention on these moments of (mis)translation, particularly through colonial stereotypes about the Mapuche. Ultimately, a focus on transcultural translation helps to determine if and how cross-cultural contacts are displaced, alienated, differentiated, mediated, stereotyped, transculturalised, or even decolonised (Gutiérrez Rodríguez 2006). Hereby, the translatability of crosscultural contact between Mapuche and non-Mapuche can help to illuminate the possibility of solidarity between both.

Transcultural translations between non-Mapuche and Mapuche are directed towards both societies. One aspect of transcultural dialogue is the filtering of material and immaterial cultural elements of the Mapuche society into the dominant Chilean national culture through the hands of prominent Mapuche individuals with some degree of public visibility. Mapuche chef José Luis Calfucura (interview with the author, February 16, 2016b) suggests the term "to filter" to describe transcultural translations and interventions by prominent Mapuche figures into the non-Mapuche society. These actors perform the task of "cultural brokers," who have an "enhanced critical competence for managing complex processes of cultural translation with regard to their political and ethical dimensions, as well as to their deeper power-related structures" (Bachmann-Medick 2016, 44). José Luis Calfucura describes them as publicly visible members of the Mapuche society, who have a deep knowledge about both the Mapuche and Chilean societies and cultures, seeking to filter the former into the latter (interview with the author, February 16, 2016b). However, only a few Mapuche ${ }^{55}$ have achieved a level of public visibility within the Chilean civil society that enables them to claim to be such filters and brokers.

The problematic aspect of this notion is that becoming a filter for one's minority is considerably male-centred and depends on hegemonic cultural codes like economic success, respectability, and the level of integration, amongst others. There is the danger that these Mapuche filters become absorbed by

55 Being a considerably famous chef, José Luis Calfucura has achieved some level of public visibility within the Chilean civil society through his participation in television shows or through reports on his work in newspapers. Other persons who could be considered Mapuche celebrities are the journalist Pedro Cayuqueo, the football player Jean Beausejour, or the politician Francisco Huenchumilla. 
a dominant anti-Mapuche, Chilean national culture and that their realm for transcultural filtering becomes restricted. On the other side, persons of this Mapuche elite are viewed critically within the more politicised sectors of the Mapuche society as sellouts or traitors who have lost contact with their territory and people.

As a non-Mapuche Chilean citizen, Juan Fuenzálida describes transcultural translations as building bridges between the Mapuche and nonMapuche societies. To build bridges thus can serve to make sense of the efforts by non-Mapuche, who provide the ground on which a transcultural dialogue can take place on the basis of mutual respect and equality. Tirúa, where the work of the JMM is located, means 'place of encounter' in Mapuzugun. Their mission is "to build bridges [...], so that there are not two divided worlds" and "to build bridges of communication, commitment, trust" (Juan Fuenzálida, interview with the author, March 12, 2016). For Juan Fuenzálida, building bridges means providing possible transcultural encounters between two divided worlds, the Mapuche and the national-Chilean, as well as alternative channels of communication to the right-wing media in Chile. He closes his statement by noting that his own involvement managed to transform his family's perspective on the Mapuche and the conflict. In his metaphor, he considers himself a bridge on which his own family is walking towards a transcultural dialogue and encounter that serves to deconstruct their stereotypes.

One everyday aspect of the work of the JMM in Tirúa and the JUPIC in Temuco is to provide spaces for a political dialogue between Mapuche representatives and those of the Chilean state. Such spaces have been criticised by some Mapuche communities and organisations, rejecting their lack of horizontality. Instead, the efforts of the JMM and JUPIC strive that "the voice of the peñis instead of ours is heard" (Juan Fuenzálida, interview with the author, March 12, 2016) so that "the people empower themselves a bit more in the decision-making" (Fernando Díaz, interview with the author, March 26, 2016). They do not aim to represent the Mapuche society, but rather to provide spaces of transcultural dialogues on horizontal and equal terms. With these conditions, they demand that the Chilean state respects and engages with the cultural politics of autonomy of the Mapuche.

Transcultural translations and dialogues not only try to communicate or visualise Mapuche culture to a non-Mapuche world but also transform the latter. In that way, Mapuche organisations, communities, and individuals transform and transculturalise the Eurocentric and Western-centred national cul- 
ture in Chile and beyond through immaterial and material elements of their culture and cosmology. I understand this to be the meaning of the term "Mapuchising," which has been articulated by José Luis Calfucura (interview with the author, February 16, 2016b), as well as by Victor Carilaf (interview with the author, February 23, 2016).

I understand the notion of Mapuchising as a transcultural practice of dialogue and exchange with non-Mapuche, which introduces Mapuche cultural elements into the hegemonic culture, but is sensitive towards the power imbalances between both. Mapuchising seeks to popularise and revitalise Mapuche culture in a way that ultimately transforms the cultural hegemony. This transculturalisation further destabilises the colonial dominance within the hegemonic culture and instead introduces Mapuche elements. As a consequence, the hegemonic culture becomes incomprehensive without taking into consideration its Mapuche impact.

Two autonomist Mapuche organisations, Wallmapuwen and AMCAM, have managed to become actors in the Chilean political system and thus contribute to its transformation. Wallmapuwen introduced itself successfully as an autonomist political party and in that way shifted the political landscape. Instead of considering Wallmapuwen as an expression of the acculturation and assimilation of political expressions of the Mapuche, this party rather transculturalises the political situation in Chile. By speaking Mapuzugun in public and aiming to establish an autonomist government in Wallmapu, Wallmapuwen has visibly defied the monocultural politics in Chile.

Similarly, AMCAM has become a mediator within the Chilean political system between the Mapuche-led municipalities and the national government. AMCAM thus disrupts the traditionally centralist nexuses between municipalities in Wallmapu and the central government and reconnects these relations through its mediation. It further makes connections between Mapuche-run municipalities and strengthens their position in negotiations with the central government. In summation, it introduces and strengthens Mapuche threads of influence within the national political culture of Chile.

The pedagogical collective Kimeltuwe aims to Mapuchise the social media spheres via transculturalising and decolonising strategies; they do not only intend to introduce terms in Mapuzugun in social media but in fact aim to use Facebook or Twitter exclusively in Mapuzugun. ${ }^{56}$ The challenge of Ma- 
puchising social media is that it requires changing the very way it is used, not only introducing different content (Victor Carilaf, interview with the author, February 23, 2016). Digital Mapuche activism therefore seeks to transform and transculturalise the ways in which online communication is carried out.

Furthermore, the arena of tourism has been taken up by transculturalisation efforts by the Mapuche in Wallmapu. The Mapuche touristic project in Llaguepulli aims "to do tourism from our logic, from our culture, from what we know" (Mauricio Painefil, interview with the author, March 10, 2016). In that way, Mauricio Painefil goes on, it is possible to "create bonds, connections with different people who come from different parts of the world" (Ibid.). Tourism is thus transformed by these efforts, not only by introducing certain elements of the Mapuche culture into the dominant arena, but by transforming the very way such an enterprise is carried out.

Finally, the transnational advocacy and international solidarity of the Mapuche diaspora contribute to such processes of transculturalisation. For example, religious ceremonies like the wetripantu are transferred to Europe and carried out according to the traditional procedures. Such activities provide a space for transcultural encounters and translation for the diasporic Mapuche from different European countries, as well as for their invited non-Mapuche friends and families. This stands in sharp contrast to the experiences in Chile, where important celebrations of the Mapuche like the wetripantu or the nguillatun ${ }^{57}$ are still carried out as exclusively Indigenous celebrations without the participation of non-Mapuche. ${ }^{58}$

Ultimately, transnational advocacy and international solidarity become activities and encounters that are transculturalised by the agency of Mapuche representatives. Non-Mapuche actors and organisations are thus confronted with these transculturalisation efforts. In that way, the presence, agency, and the cultural politics of autonomy of the Mapuche in Europe disrupt and challenge monocultural, Eurocentric understandings and social practices of advocacy by non-Mapuche.

57 The nguillatun is maybe one of the most important and highly complex ritualised celebrations in Mapuche communities. It is usually celebrated once a year.

58 For example, the Mapuche journalist Pedro Cayuqueo (2012,177-79) expresses his desire for transcultural religious experiences in Chile inspired by his trip to North America, where celebrations of the First Nations like the Pow-Wow are visited in a respectful manner by many non-Indigenous people. 
This chapter discussed the heterogenous field of transnational Mapuche advocacy (TMA) as well as its different strategies and tactics. TMA is essentially led by Mapuche representatives travelling abroad, the Mapuche diaspora in Europe, and multiple non-Mapuche supporters and organisations. Since political articulations of Mapuche communities and organisations in Chile are largely impeded, together with their international allies they increasingly make particular and structural injustices internationally visible. TMA hereby engages within the master frame of Indigenous and human rights, which nevertheless has some colonial contradictions and limitations. TMA further amplifies the injustice frame of the dictatorship under Augusto Pinochet in Chile, seeks to transform the racialising frame that puts the Mapuche resistance on the same level as terrorism, and, finally, extends the frame of ecological justice to include the political aims of Mapuche organisations and communities.

The rest of the chapter outlined four central strategies of TMA. The most important strategy involves the informational politics that produce different forms of alternative information about the situation in Wallmapu, with the goal of pluralising information and raising awareness and sensitivity. I particularly focused on the usage of information and communication technologies (ICTs) amongst Mapuche organisations, collectives, and communities by giving an overview of its central actors, discussing new developments and contradictions concerning digital Mapuche media and activism, and by situating it within the constraints and limitations by contextual, mostly political and socioeconomic factors. In summation, digital Mapuche media and activism have become powerful instruments against the everyday repression in Wallmapu and for transnational pluralisation and consciousness-raising. At the same time, it opened another (digital) front, on which their resistance and struggle is contested by powerful and resourceful actors.

As a second strategy, TMA creates transnational pressure through a heterogenous set of symbolic, leverage, and accountability politics. In particular, actors of the Mapuche diaspora hereby transnationalise, translocalise, and transculturalise protest tactics from Wallmapu, like the funa, to the European context. Most of these political strategies are contingent, limited to particular, campaigns and performed in a cyclical manner, for example by commemorating a certain date or being organised alongside the visit of the Chilean president. In those campaigns, particular groups and actors come together and form the networked structure of transnational advocacy and solidarity. TMA also seeks to create leverage and to hold powerful actors accountable. Those are institutions like the UN in Geneva, the EU, the International Court 
of Justice in The Hague, other national governments or state representatives, as well as private companies. However, these strategies have rarely been successful and need to be considered under the colonial limitations and contradictions within the international human and Indigenous rights structure.

Considering these limitations, I outlined a strategy of TMA that seeks to fortify Mapuche organisations and communities directly. I discussed the possibilities and limitations of supporting Mapuche communities and organisations by drawing on two case studies that include financial donations. In conversation with Mapuche interlocutors, I outlined the limitations of such approaches and how financial donations contribute to reproducing colonial relations, dependencies, and stereotypes. In contrast, and by presenting the efforts of the Mapuche cooperative Kvme Mogen, I discussed what a decolonial economic solidarity with Wallmapu could look like.

Finally, this chapter detailed how different actors of TMA engage in transcultural dialogues and translations. I first presented the importance of having a dialogue within Mapuche culture and political spaces, expressed through notions like matetun, ragiñelwe, trawvn, and koyang. Within this strategy, some Mapuche actors take up the role of transculturalising filters towards the nonMapuche world, whilst non-Mapuche describe themselves as bridges between the non-Mapuche and Mapuche societies. Finally, I showed how political and sociocultural spaces of articulation and intervention become Mapuchised, disrupting and challenging monocultural and Eurocentric social, cultural, and political practices. This includes the Mapuchisation of TMA and international solidarity.

Within TMA, an infinite number of encounters and disencounters between Mapuche and (Chilean and European) non-Mapuche actors take place. They all bring their different motivations, expectations, positionalities, and privileges into this crowded field of solidarity and advocacy activism. The following chapter will critically discuss how the whiteness, understood as a position of privilege, of non-Mapuche influences these encounters and how colonial and racialised stereotypes complicate the terrain of international solidarity. 